\title{
An Overview on the Production of Bio-briquettes from Agricultural Wastes: Methods, Processes, and Quality
}

Philip Donald C. Sanchez a, ${ }^{*}$, Mia Me T. Aspe a, Kenneth N. Sindol a

aDepartment of Agricultural and Biosystems Engineering, College of Engineering and Geosciences, Caraga State University, Butuan City, 8600, Philippines. ${ }^{b}$ Center for Resource Assessment, Analytics and Emerging Technologies (CReATe), Caraga State University, Butuan City, 8600, Philippines.

\section{ARTICLE HISTORY}

Abstract

Received: 2 September 2021

Received in revised form: 11 February 2022

Accepted: 21 February 2022

Available Online: 3 March 2022

\section{Keywords \\ Bio-briquettes \\ Agricultural Wastes \\ Briquetting \\ Bindering \\ Densification \\ Pyrolysis \\ Proximate Analysis}

Global energy demand is expected to increase in the next few years due to the corresponding increase in the world's population. The world's increasing energy demand is the ultimate reason to utilize alternate sources such as renewable energy. There are various forms of renewable energy sources. However, biomass is the always widely available source of renewable energy worldwide. Agricultural wastes such as rice husks, corn cobs, and bagasse results from various agricultural activities. These wastes are commonly left piled in the field to decompose or burn in open fires which consequently provide risks to the environment and animal and human health. The bio-briquettes product is suitable as an energy source commonly used for electricity generation, heat, and cooking fuel. They are the perfect replacement for wood logs. Hence, this review paper provides an overview of the utilization of various agricultural wastes into bio-briquettes. This review discusses the production, characterization, processing (preparation, size reduction, pyrolysis, binder addition, and densification -shaping and sizing), and quality evaluation methods of briquettes. This comprehensive review also presents the technology advancements, challenges, and future trends in the bio-briquetting industry.

\subsection{Introduction}

The use of renewable and nonrenewable energy sources is increasing all around the world. Over the years, the growth in energy needs by constituents has been efficiently exploited day after day. Each country's community needs an alternative energy source in order to reduce fossil fuel usage that is ecologically friendly and ready for long-term use. Renewable energy sources such as solar, biomass, wind, and geothermal are abundant in nature. Solar energy comes from the sun, which supplies our entire planet with the energy we need to survive. Using solar panels, we can harvest energy directly from sunlight and convert it to electricity that powers our homes and businesses. Wind turbines capture the wind's power as they spin and convert it to electricity. Geothermal energy within the earth can be harnessed to generate electricity. It is a renewable energy source that has the potential to enhance our environment, economy, and energy security dramatically (Uzun \& Kanmaz, 2013). On the other hand, nonrenewable resources such as coal, oil, fossil fuels, and natural gas, have been depleted. These constraints will lead to fuel scarcity and an increase in price (Sirajudin et al., 2013). There are various forms of renewable energy sources. Biomass is one of the important sources of renewable energy. Bio-briquettes provide a solution that is mostly made of green waste and other organic materials, and is commonly used for electricity generation, heat, and cooking fuel. They are the perfect replacement for wood logs.

In the present time, the increasing energy needs of the world and the continually growing population tend to result in a bunch of waste and higher energy demands. The consumption of several agricultural products has regularly left the stems, leaves, and peels from the tree either being wasted or thrown away. Producing bio-briquettes can also intensively help to address the increasing demand for energy. There are numerous researches have been carried out in sourcing for solutions to reutilize these organic wastes by turning them into something beneficial to mankind. Large quantities of vegetable and fruit wastes are left unused or allowed to decompose creating serious environmental problems. Nonetheless, these problems can be overcome by generating bio-briquettes that are affordable, renewable, and sustainable.

Global communities such as Asia and Africa have the highest domestic supply of biomass and the majority of it is primary solid biofuels. Asia and Africa hold the majority share of biomass because of the extensive use of charcoal and wood as fuel for heating, cooking, and other domestic uses (World Bioenergy Association, 2019). Over the previous years, biomass has been considered the third largest energy source in the world. Additionally, biomass can be defined as any organic matter that is available on a renewable or recurring basis that includes energy crops and trees, agricultural food and feed crops, agricultural crop wastes, wood wastes, aquatic plants, animal wastes, municipal wastes, and other waste materials, which recognized as one of the major potential sources for energy production (Sivakumar \& Mohan, 2010).

Furthermore, the exploitation and utilization of biomass resources can solve the disposal problems caused by a large amount of agricultural and forestry waste annually and eliminate the potential environmental pollution (Tan et al., 2017). Utilizing biomass wastes into a consumable and sustainable outcome can diminish environmental issues due to improper disposal of some agricultural wastes. The advantages of using the biomass bio-briquettes are as follows: (1) costeffective; (2) renewable source; (3) no sulfur and therefore it is unable to pollute the environment; (4) it has a higher calorific value than other solid fuel sources; (5) ash content in biobriquettes is lower than coal at $2-10 \%$ and $20-40 \%$, respectively; (6) its combustion is more uniform compared to 
coal; (7) they produced near the consumers; therefore, supplies are not dependent on transportation over long distances; and (8) due to the low moisture content and higher density, it provides much higher boiling efficiency compared to firewood or waste biomass (Sharma et al., 2015). Therefore, biobriquettes generally have better energy parameters, higher density, calorific value, and lower water content than other raw materials (Stolarski et al., 2013).

Over the past ten (10) years, there have been several researches about the development of biomass briquettes from different organic wastes. There are limited existing comprehensive studies about the process, methods, and utilization of biomass from different agricultural waste. Say, for instance, Ifa et al. (2020) focused on bio-briquette from cashew nutshell waste; Nuriana et al. (2014) widely discussed the durian peel bio-briquettes as an alternative fuel; and Ahmad et al. (2018) mainly focused on the characterization of fuel briquettes from banana tree waste. However, there has been no inclusive review conducted focusing on the processes and methods involved in briquetting the various agricultural wastes. Bio-briquettes are more sustainable and energy-efficient for heating energy due to its affordability, accessibility, and versatility for meeting people's needs. It offers a low cost for cooking, heating homes, and powering industrial activities that are more beneficial than other products. However, the production and quality evaluation process differ depending on the waste being utilized. Thus, it is the primary goal of the present study to give a comprehensive overview of the production of bio-briquettes from agricultural wastes including its methods, processes and quality. Additionally, this paper will be a great help in the agricultural sector, particularly farmers and biomass fuel producers to know about briquette production and utilization methods. Likewise, this specific review will be beneficial to researchers who get involved and are concerned with the utilization of bio-briquettes as an alternative source of energy.

\section{Overview of agricultural waste production}

Agriculture is one of the largest biological sectors with the highest biomass production (European Commission, 2015), which becomes an essential input for the bio-economy,(Bracco et al., 2018; European Commission, 2017b). This represents a great opportunity because it contributes to the development of new green markets and jobs by promoting the conversion of agricultural waste that includes vegetable and fruit waste into value-added products such as food, feed, bio-products and bioenergy (European Commission, 2017a; Scarlat et al., 2015). However, as the population gradually grows day by day, the food and energy demand continues to increase. Agricultural production has increased more than three times over the last 50 years because of the expansion of soils for agricultural use; the technological contribution of the green revolution which influenced productivity; and the accelerated growth of population (FAO \& OECD, 2019). By this, it is expected that the more growing numbers of production, the more agricultural wastes will surmount. Agriculture produces an average of 23.7 million food tons per day worldwide (FAO, 2017). Additionally, agricultural waste is defined as wastes during the production and processing of food and fiber on farms, feedlots, ranches, ranges, and forests which may include animal manure, crop residues, and dead animals; and also agricultural chemicals(residues and containers) that to contribute contaminants to surface and subsurface water (Quartey, 2011). Moreover, a significant increase in agricultural wastes is observed globally as developing countries intensify their farming systems. It is estimated that 998 million tons of these wastes are produced annually (Obi et al., 2016). The composition and amount of agricultural residue produced vary on different biomass; and many more.

Various researches have been made to analyze the potential of different agricultural waste for energy consumption. Briquetting is one of the sustainable methods to provide an alternative solution for an energy source. The process of briquetting involves the compression of a material into a solid product of any convenient shape that can be utilized as fuel just like the use of wood or charcoal. This is a conversion of combustible materials that can be found in the waste stream to utilize the waste into wealth. Some processes convert agricultural wastes into value-added material. It can be used as (1) Organic Fertilizer - animal manure (cattle, goat, bird, etc.) is used to improve the soil's physical and chemical properties and serve as a source for additional nutrients for growing crops. It is formed into pellets for better storage and handling of manure, for easier application in land crop fertilization, and able to conserve all the properties of original material (Mieldažys et al., 2016); (2) Food Packaging - it has been proven that PVA reinforced with lignocellulose nanofibers from agricultural wastes namely tomato, pepper, and eggplants crops can produce food packaging films with improved thermal resistance, water vapor permeability, and mechanical properties (Villegas et al., 2021); and for (3) Energy resource- numerous research have been made to analyze the potential of different agricultural waste for energy consumption including Briquettes. According to Kpalo and Zainuddin (2020), residues that are utilized for bioenergy resources are crop residues (wastes left after farm harvesting) such as straw, leaves and stalk of rice, maize/corn, sorghum, millet, cassava stalk/peelings, and cocoa pods; and process residues (wastes after processing) such as corn cob, corn husk, coconut shell and husk, rice husk, oilseed cakes, sugar cane bagasse, and empty fruit bunch (EFB) of palm. Figure 1 shows the samples generated from agricultural activities. These are some of the wastes often neglected which has the potential to convert into combustible biomass briquettes would provide a means to satisfy individual energy needs while alleviating landfill use; (a) Cacao fruit skins, (b) Coconut fruit skin, (c) Durian fruit skin. The composition and amount of residue produced vary on different biomass.

As science and technology advances, the emergence of new methods on how to improve the value of various agricultural wastes is highly projected in the future. Identifying the most suitable value-adding method significantly depends on the characteristics of agricultural wastes (chemical components, moisture content, physical characteristics, etc.), the availability of machines for a certain type of production, the consumers' demand in the locality, initial investment cost, and many more. However, with the growing problem of energy scarcity and the high emission of GHGs, adapting to renewable energy resources such as bio-briquetting is highly needed. According to Patil (2019), briquetting production is an emerging, eco-friendly, cost-effective, and profitable technology for the use of agricultural residues. Briquetting can be the best considerable option as a value-adding method for agricultural wastes that are abundantly produced in the vicinity, has a very low nutritive value to be utilized to other products, and are commonly open burned by the farmers. Moreover, Romallosa and Kraft (2017) have stated that briquette production as a livelihood would help the informal sector to increase their income. Even with the use of a low-cost machine, it can serve as an alternative/additional livelihood to urban and rural communities. 

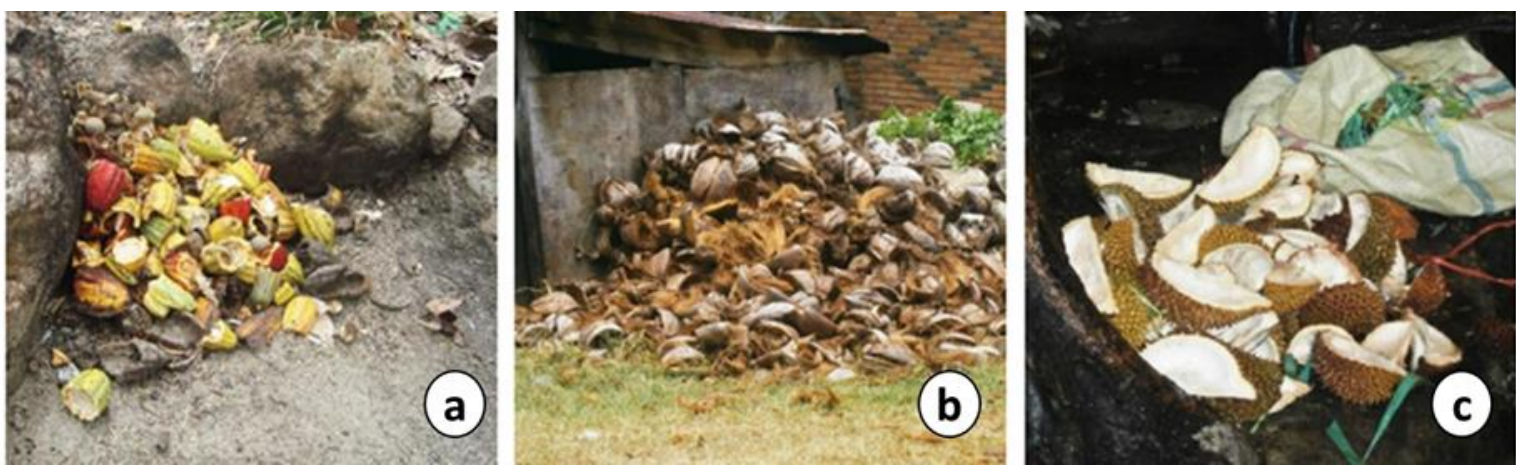

Figure 1. Example of Agricultural Wastes, from left to right: (a) Cacao fruit pods, (b) Coconut fruit skin, (c)Durian fruit skin. Source: (Brunerová et al., 2017)

\section{Overview of bio-briquettes from agricultural wastes}

The agricultural industry residues and wastes constitute a significant proportion of worldwide agricultural productivity. Although the quantity of wastes produced by the agricultural sector is significantly low compared to wastes generated by other industries, the pollution potential of agricultural wastes is high on a long-term basis (FAO \& OECD, 2019). In addition, agricultural waste is defined as unwanted waste produced as a result of agricultural activities and converting these wastes into briquettes is a great avenue to propose another renewable solution.

Bio-briquetting is the process of increasing the density of biomass through using compaction of the original loose particles by application of mechanical force. Among the advantages of bio-briquetting include creating a bond within the particles to form a solid fuel, decreasing the moisture content of the biomass, increasing the net caloric value per unit volume because of the removal of volatile matter, producing uniform size and quality fuel, ease transportation and storage, and help addresses residue disposal problem (Kaur et al., 2017; Gurdil \& Demirel, 2018). Bio-briquettes are renewable, unlimited in resource, clean, cost-effective, and carbon-neutral energy because the Carbon dioxide $\left(\mathrm{CO}_{2}\right)$ released from burning are reabsorbed by the plant (Shuma \& Madyira, 2017; Handra et al., 2018; Kpalo et al.,2020). Bio-briquette is both used in urban and rural areas for domestic (cooking, barbecuing) and industrial purposes (Maninder et al., 2012). Moreover, bio-briquettes from agricultural wastes are sustainable, eco-friendly, healthy, and not dependent on fossil fuel. The charring of feedstock prior to pelletization into briquettes is capable of maximizing the calorific value and minimizing combustion emissions (Obeng et al., 2020). Therefore, the need for the production of briquettes at low cost and in abundance to increase its potential to replace firewood, charcoal and fossil as domestic cooking and heating fuels.

Agricultural wastes that were studied for characterization, evaluation and production of bio-briquette are but not limited to rice husk \& coffee husk (Lubwama \& Yiga, 2018), rice husk and bran (Yank et al .,2016); palm oil empty fruit bunches (EFB) (Maitah et al., 2016); sugarcane bagasse and sugarcane leaves (Saputro et al., 2020); tropical fruit wastes - durian fruit, coconut fruit, coffee fruit , cacao fruit, banana fruit and rambutan fruit (Brunerová et al., 2017); rice husk (Suryaningsih et al., 2018); corn cob and rice husk (Nurhayati et al., 2016) ;cornstalk (Wang et al.,2017); durian peel with biomass coconut and palm shell
(Sari et al. 2018); durian shell (Irhamni et al., 2019); durian peel and bagasse (Haryati et al. 2018); nutmeg seed shells (Idris et al.,2018); bamboo fiber and sugarcane skin (Brunerová et al., 2018); banana leaves (Maia et al., 2014), cotton dust (Suvunnapob et al., 2015); cotton stalk (Wu et al., 2018), blend of areca nut husk, simarouba seed shell (Ujjinappa \& Sreepathi, 2018), cashew nut waste (Ifa et al., 2019). Some briquette production uses one type of biomass in processing while others use the combination of two or more biomass to take advantage of individual uniqueness thus producing better combustibility, more improved physical and chemical characteristics, and durable briquettes (Okot, 2019).

Aside from agricultural wastes, other biomass resources such as forest residues are also utilized for biobriquetting production. For instance, the study of Fadele et al. (2021) showed that jatropha seed shells (JSSs) and Eucalyptus camaldulensis wood shavings (EcWSs), a forest undesirable wastes, with Acacia senegal as a binder material are potential to be utilized for the production of biobriquettes; while in the study of Brožek et al. (2012), Wood wastes such as wood dust, sawdust, shavings, chips, and bark -a fine-grained loose wastes resulting from logging and subsequent wood and wood semiproducts treatment, are being assessed for briquetting. The study found out that briquetting from these wastes requires more pressure, which could be done by reducing the pressure chamber diameter or lengthening the pressure chamber.

\subsection{Characteristics of Bio-briquette}

Biomass briquettes do not increase the carbon footprints and are highly advantageous over other cooking fuels like wood in terms of quantum of heat generated per unit mass, moisture content, and storage space. According to Kpalo et al. (2020), there is an increase of $20 \%$ in the combustion properties of densified biomass and emit only $1 / 9$ of greenhouse gases, $1 / 5$ of nitrogen oxides (NOx), and $1 / 10$ of sulfur dioxide $\left(\mathrm{SO}_{2}\right)$ compared to coal. The briquetting of biomass material leads to an increased net calorific value per unit volume, reduces transportation cost, improves bulk density, and also improves handling characteristics (Tiwari et al., 2011). Moreover, Solano et al. (2016) added that bio-briquettes also provide social and economic benefits to farmers such that more jobs are created in rural areas, strong support to local and regional businesses, can decrease dependence on energy imports, and among others. Table 1 shows the comparison of the characteristics of different fuel types - briquette, coal, and firewood.

Table 1. Characteristics of different biomass fuels. Source: (Maitah et al., 2016)

\begin{tabular}{llll}
\hline Fuel Type & Caloric Value $(\mathrm{MJ} / \mathrm{kg})$ & Ash Content & Other Factors \\
\hline Briquette & $17.58-20-10$ & $0.5-8$ & No sulphur and Smoke \\
Coal & $15.07-18.84$ & $30-50$ & Aromatic contents and Smoke \\
Fire Wood & $9.21-12.98$ & $20-25$ & High Smoke \\
\hline
\end{tabular}




\subsection{Factors of Biomass Selection}

Bio-briquette is a kind of renewable briquette that grows fast in the fuel market today. Many factors will influence the biomass selection required for making decisions.

Availability of biomass: The biomass waste selected should be abundant in quantity within the locality. The districts with greater production of wheat residue biomass according to the estimates considered the most appropriate (Román-Figueroa et al., 2017). Moreover, it should have low nutritive value, high caloric value, and low ash content.

Energy consumption priority areas: These were established according to the energy demand scenarios previously calculated: high demand, social demand, and potential demand. The selected sectors with a high demand were considered a priority and more suitable.

Land use/coverage: The installation of an energy production plant must comply with the legal requirements and land usage. Competition with other current uses of the land must be avoided, allowing current activities to continue. The areas considered feasible for the installation of a plant were those without vegetation, meadows, or scrub and were industrial use lands. Urban areas and lands of agricultural use were considered unsuitable because other activities are carried out there that are relevant to society (Bili \& Vagiona 2018).

Roads: Connectivity is essential for the supply of raw materials to the plant; thus, the transport of raw materials should be considered (Capilla et al., 2016; Uyan, 2013). Therefore, a maximum distance of $1.0 \mathrm{~km}$ between the energy plant and the road was considered a priority. Moreover, the type of road material affects accessibility, and thus, this was considered a factor.

\section{Bio-Briquetting Process}

In bio-briquette production, there is no specific flow followed. The following are the basic components used in the briquette processing system, and the arrangement of the flow depends on the method used that will be discussed in the following part of this paper. Bio-briquette processing components may include the preparation of biomass (collection of wastes, cleaning, and storage), biomass drying, size reduction (crushing, grinding, etc.), pyrolysis, binder addition, densification including sizing and shaping, and briquette drying (El-Haggar, 2005; Kpalo et al., 2020; Maninder et al., 2012).

\subsection{Preparation}

Cleaning: Collection of the wastes followed by cleaning and sorting is done to remove impurities from the biomass such as metal, plastic strings, dirt, soil, etc. through sieving or by the use of screening equipment and magnetic conveyors. Foreign materials affect the performance of machines during processing as well as the quality produced (Kpalo et al., 2020).

Storage: Proper storing of biomass is essential to allow natural drying to minimize the need of drying the material for a long time just to achieve the required MC for the densification process. The piled raw material can be stored in building sheds or can be covered with geotextile to avoid mixing with sand, stone and other impurities (Solano et al., 2016).

Drying: The process of reducing moisture content (MC) of biomass to the minimum required is essential to initiate the densification process. The acceptable moisture content should be between 5-15\% (Solano et al., 2016). Drying can be done through natural drying or forced drying. Natural drying is defined as a method where biomass is exposed to solar radiation and wind to allow material to be dried naturally without heating externally. The hours and days used in natural drying depend on the moisture content of the commodity, and the surrounding temperature and humidity. Material moisture content should be reduced to the optimum level required for densification. (Solano et. al., 2016; Suryaningsih et al., 2018). On the other hand, Forced drying is defined as the industrial process to reduce the moisture content of biomass fuel down to a specified range (5$15 \%)$ suitable to start densification. Machines used for forced drying include the Direct dryers (Pneumatic) where biomass is circulated all throughout an external tunnel, and dried by hot and dry air in direct contact with the wood; and indirect dryers (rotary drum or trommel) where biomass is spinned in a heated, rotating cylinder. Biomass is dried by contact with the hot internal surface of the Cylinder. Indirect dryers are usually used when the moisture content of the biomass is more than $50 \%$ (Solano et al., 2016). Between the two drying processes, sun drying (natural drying) is more simple and cheaper, however highly dependent on the weather condition compared to mechanical drying (forced drying) (Ifa et al., 2020).

According to Lonia (2005), several Agricultural wastes have a moisture content greater than green wood which is $50-55 \%$ thus needing maximum energy to be dried. The researcher further stated that waste can be dried in the sun up to $20-25 \%$ moisture and later by thermal process up to $5 \%$. Other materials such as chips and powdery materials are commonly dried in entrained beds or flash pneumatic dryers.

Moreover, the biomass should have low moisture content for it affects the densification process and briquette's quality, has high caloric value, low ash content with lower than $4 \%$ because greater than this may cause slagging (Dinesha et al., 2019; Kpalo \& Zainuddin, 2020). Drying the biomass before the briquetting process is done to decrease its moisture content (MC) to $5-15 \%$, which is the acceptable MC for densification (Solano et al., 2016). Figure 2 illustrates the Biomass preparation for briquetting process it includes cleaning, storing, and drying.

\subsection{Size Reduction}

For easy handling, transportation and combustion, agricultural wastes are cut into smaller sizes (Lonia, 2005). Size reduction depends on the biomass, but it can be classified as chopped $(50-250 \mathrm{~mm})$; chipped $(8-50 \mathrm{~mm})$ or ground $(<8 \mathrm{~mm})$ (Solano et al., 2016). Straw and Stalk types are chopped by chaff cutters into granular and sticks are shredded (Lonia, 2005); bulky biomass are chopped into small pieces to improve their workability and compactness such as groundnut waste, bagasse,

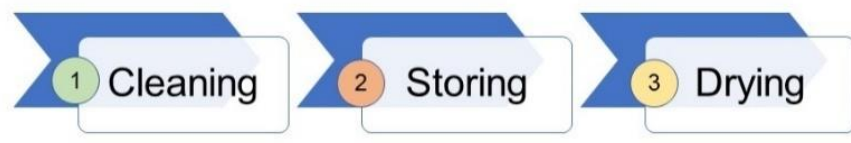

Figure 2. The Common Briquetting Preparation Process: (A) Cleaning, (B) Storage, and (C) Pre-drying Adapted from: Solano et al. (2016) 
wheat straws, barley, maize straws and cobs, and many more (Kaur et al., 2017); Others are ground into smaller particles such as $<0.1 \mathrm{~mm}$ for durian peel, coconut, rambutan, cacao, coffee, banana wastes using Hand mill (Brunerová et. al., 2017); less than $0.1 \mathrm{~mm}$ for Bamboo fiber and Sugarcane skin using a cutting mill (Brunerová et al., 2018); and 2-5 mm and 7-10 mm for Hazelnut husks and sunflower residue (Gurdil \& Demirel, 2018). There are also briquetting processes that pyrolyzed first the agricultural waste before sieved into the required size.

In addition, the review article of Gurdil and Demirel (2018) stated that the particle size of feedstock has a great impact on the quality of briquette produced including its compressibility and durability. Smaller particle size resulted in density, mechanical strength, hardness, mechanical durability, impact resistance, and the burning time of briquette to increase. Furthermore, the study showed that the smaller the particle size of biomass, the smoother the surface of the produced briquettes which is an indicator of good quality mostly for commercial purposes. According to the study of Saptoadi (2008), smaller particle size produces higher density briquettes and lesser porosity which causes a lower combustion rate and higher combustion period. The study observed that the largest particle burns only for 19.25 minutes while smaller particles burn for 28 minutes. In addition, Maninder et al., (2012), stated that the finer the particles, the easier the compaction process and provide a larger surface area for bonding. It also partially breaks down the lignin component of biomass and increases total surface area thus the stronger the inter-bonding of particles (Kpalo et al. 2020).

On the other hand, Gurdil and Demirel (2018) have also stated that processing biomass into fine particles requires more energy (mostly during grinding especially those hard shells residue and those briquetting process that undergoes pyrolysis) which leads to the production cost increase and longer fuel ignition time of briquette. Therefore, determining the particle size in briquette processing should provide both good quality briquettes and cost-efficient production. Common equipment used in size reduction are Hammermill, knife mill, linear knife grids, and disk attrition in which hammer mill is considered as the most suitable to use followed by cutting mill (Kpalo et al., 2020).

\subsection{Pyrolysis}

According to Zhang et al. (2019), pyrolysis is defined as the thermal decomposition of biomass in the absence of oxygen at medium $\left(300-800^{\circ} \mathrm{C}\right)$ to high temperature $\left(800-1300^{\circ} \mathrm{C}\right)$ that produces solid, liquid and gaseous. Moreover, pyrolysis can be classified into two - (a.) conventional or slow pyrolysis in where carbonization and torrefaction processes belong. This is used for briquette production because it produces a higher percentage of solid than liquid and gas; and (b.) the fast and flash pyrolysis which produces liquids and gaseous products. Torrefaction and Carbonization just differ in temperature. The former has a temperature range from $220-300^{\circ} \mathrm{C}$ while the latter starts from $400^{\circ} \mathrm{C}$ (Mari, 2014). Accordingly, torrefaction is slow pyrolysis ranging from $200-300{ }^{\circ} \mathrm{C}$ in where feed material is heated with $50{ }^{\circ} \mathrm{C} / \mathrm{min}$ (hours to days) to release the volatiles and remain carbon rigid structure; and loss of water remove water that inhibits the caloric value of biomass and (carbon monoxide),(carbon monoxide),(hydrogen), and (methane). The material produced retains $70 \%$ of its mass and $90 \%$ in energy content.

In briquette production, the torrefaction process changes the physical and chemical properties of biomass thus improving the quality of briquette produced. Mukhtar et al.(2020) stated some characteristics of biomass after being torrefied - include lower Oxygen/Carbon ratio, improve grindability, increase energy density from $15-30 \%$ which enhances combustion performance, and increase in caloric value from 17-19 MJ/kg to 18-29 $\mathrm{MJ} / \mathrm{kg}$. In addition, torrefaction causes briquette to become hydrophobic or the ability to not reabsorb moisture during storage - otherwise, the heating value will decrease thus affecting the burning capacity of the briquette (Haryati et al., 2018).

There are various technologies used for torrefaction applications such as a.) auger reactor, described as having accurate temperature control due to limited heat transfer, requiring long residence time $(60-90 \mathrm{~min})$, allowing only freeflowing material to operate properly, biomass ratio is $60-70 \%$; b.) rotary drum, simple in design and has a rotating cylinder with metal bars along its circumference to tumble the biomass, good heat transfer due to the permanent mixing of biomass. In comparison, the Auger reactor provides better performance compared to a rotary drum with a directly heated reactor(with $10-15 \%$ fill ratio) because of its low heat transfer coefficient and longer solids residence time; c.) Moving bed reactor, has simple and compact design with $100 \%$ fill ratio, achieves high heat transfer, short residence time and can allow non-flowing material; d.) Fluidized bed reactor, used in thermochemical conversion of biomass, has high heating rate and coefficient, stable and provides uniform temperature due to vigorous mixing and large surface area; and e.) Microwave, which uses 2.4 $\mathrm{GHz}$ frequency to thermally process biomass. Microwave torrefaction has uniform biomass heating, shorter heating time, small footprint, and accurate control (Pestaño \& Jose, 2016).

\subsection{Binder Addition}

Binding is a process of sticking together the biomass material using a specified binder which is essential for uniform briquetting formation to ease transportation and storage (Zhang et al., 2018); to minimize mold wear during compaction, improve cohesion characteristics and mechanical strength of briquettes, and aid agglomeration when the particles have weak cohesive forces (Okot, 2019). The effect of the binder on the briquette's quality depends also on the characteristic of biomass used.

According to Zhang et al., (2018), there are three types of binders used in briquetting namely organic binder, inorganic, composite/compound binder. Organic binder (biomass binder, tar pitch binder, polymer binder ex. starch binder, etc. ) shows good bonding performance, high crush strength, and drop strength but has poor mechanical strength and thermal stability at high temperature because it decomposed easier in this condition - starch binder is commonly used for it takes only 4$8 \%$ of binder to produce briquettes but it rarely used in industrial processes due to its high cost, low waterproofing, and low coking property; Inorganic binder has an abundant resource, low cost, excellent thermostability, and good hydrophilicity but produce high ash concentration; while the Composite binders are composed of two or more binders in where the unique composition of each binder type are joined together to improve the quality and performance of the biobriquette. A binder (or additive) can be a liquid or solid that forms a bridge, film, matrix, or causes a chemical reaction to make strong interparticle bonding (Kaliyan \& Morey, 2009).

Types of binder and binder ratio used affect the physicochemical properties of bio-briquette (Okot,2019); the strength, thermal stability, combustion performance and the cost of briquette (Moki et al.,2018); physical properties such as moisture content, compressive strength, compression ratio and bulk density (Wakchaure \& Mani, 2009); and on the density, caloric values, ignition and burning time (Chirchir et al.,2013). The required properties of binders for briquetting are strong bond, pollution-free, no effect on the heat release and combustibility of the coal, does not interfere with the utilization 
of the coal, environmentally acceptable, and economically available (Zhang et al., 2018).

Various researchers studied the potential of different binding types to enhance the quality of bio-briquette produced from agricultural wastes. Say, for example, Chichir et al. (2013) investigated the effect of binder types such as molasses, cow dung and clay binders to charcoal dust, rice husk and bagasse dust in the quality of briquette produced. The results showed that density, ignition time, and burning time have increased with an increased amount of all types of binder; while molasses blended briquettes provide high caloric values. In the study of Lubwama et. al (2020), the researchers have found that the combination of carbonization and the presence of binders provide a positive impact on the physical properties such as the moisture content, volatile matter, and fixed carbon on the production of agricultural briquettes made from rice husks, coffee husks, sugar cane bagasse, and ground nutshell. Meanwhile, in the study of Wakchauri and Mani (2009), it showed that briquettes prepared from mustard stalk blended with press mud at a concentration of $20 \%$ and die pressure of 123.42 MPa produces better physical properties $(75.35$ compressive strength, 8.5 compression ratio, and 1,204 bulk density) compared to molasses and distillers dry grain binders; moreover, Lubwama and Yiga (2018) have observed that briquettes with cassava starch binder show higher drop strengths (over 95\%) compared to clay binder.

On the other hand, there are briquetting processes that use a binderless method or no binder has been added. For instance, Saputro et al. (2020) studied bio-briquette production from sugarcane bagasse and leaves without the use of additives due to the natural lignin composition of bagasse. Lignin is a natural binding substance of lignocellulosic plants which acts as a glue to bond cellulose fibers (Oladeji, 2015).

\subsection{Densification}

Densification or briquetting is a process of compacting material by the application of pressure (Chaney, 2010) and is used to convert the biomass into higher density, uniform in shape, low moisture content, and increase in energy content (Kaur et al.,2017). Density after compaction determines the total energy content of briquette leading to a more improved burning rate ( Shuma \& Madyira, 2017). Five main types of presses are commonly used in densification namely piston presses, screw presses, roller press, pelletizing, manual presses, and lowpressure briquetting. In terms of pressure, pressers can be categorized as High/medium pressure compaction and Lowpressure compaction (Kaur et al., 2017; Maninder et al., 2012).

a. High/medium pressure compaction uses no additional binder and the use of energy is low. The technologies under this compaction are screw press and piston press. On the other hand, low-pressure compaction uses the help of a binder to bond the particles together - under this is the hand-molded briquettes (Kaur et al., 2017). According to Yank et al. (2016), in low-pressure densification, it is beneficial to add water up to $60 \%$ to improve homogenization of the binder through biomass and interparticle bonding. In addition, Lubwama and Yiga (2018) identified that between rice husk and coffee husk for biobriquette production, the latter successfully can be developed without binder under high-pressure compaction while the former failed. Moreover, the coffee husk is observed as having a smooth texture but has lateral cracks which can be a natural effect on briquettes due to highpressure densification.

b. Screw press (Figure 3)- biomass is extruded continuously by one or more screws through a taper die which is heated externally to reduce the friction. It has continuous output, uniform briquettes, provides a central hole for better combustion characteristic due to larger specific area, increases biomass density from 100-200 to 1200, the outer surface is partially carbonized that provides protection to ambient temperature and improve ignition and combustion, high power requirement compared to piston press. Screw press produces briquette with central hole for better combustibility combustion characteristics due to its larger specific area. Moreover, this press is suitable for small-scale applications (Maninder et al., 2012; Kaur et al., 2017).

c. Piston press (Figure 4)- categorized as the die and punch technology - biomass is punched into a die by a reciprocating ram with a very high pressure thereby compressing the mass to obtain a compacted product, standard diameter is $60 \mathrm{~mm}$, and power required is 700 $\mathrm{kg} / \mathrm{hr}$ is $25 \mathrm{~kW}$. Moreover, piston press merits and demerits are - wear of the ram, which is considerably reduced due to less relative motion between the ram and the biomass, most cost-effective technology, and the produced briquette are somewhat brittle as the carbonization of the outer layer is not possible. Screw press has better quality produced than piston (Kaur et al., 2017).

d. Hydraulic press (Figure 5)- begin compacting the biomass in the vertical direction and then again in the horizontal direction. The standard briquette weight is $5 \mathrm{~kg}$ and with a dimension of $450 \mathrm{~mm} \times 160 \mathrm{~mm} \times 80 \mathrm{~mm}$ and the power required is $37 \mathrm{~kW}$ for $1800 \mathrm{~kg} / \mathrm{h}$ of briquetting, allowing material with 22\% MC (Maninder et al.,2012).

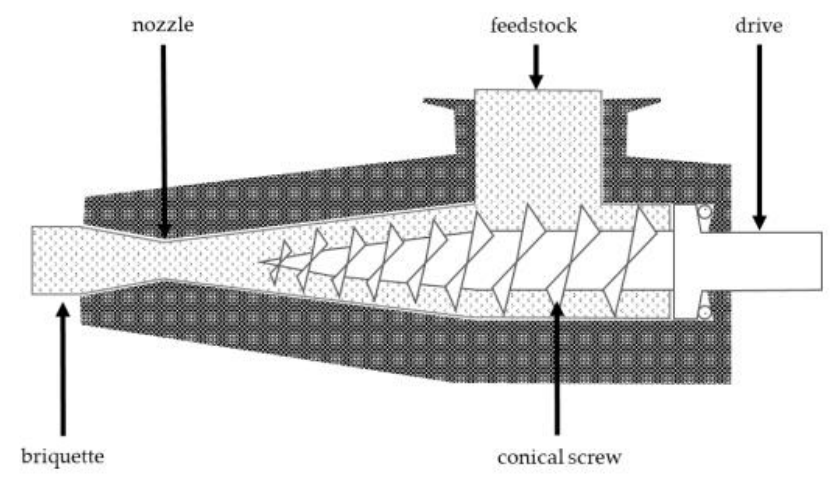

Figure 3. Screw Pres (Kpalo et al, 2020) 


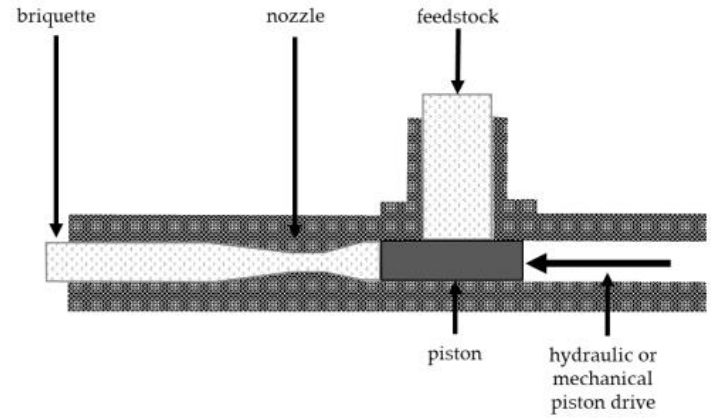

Figure 4. Piston Press (Kpalo et al., 2020)
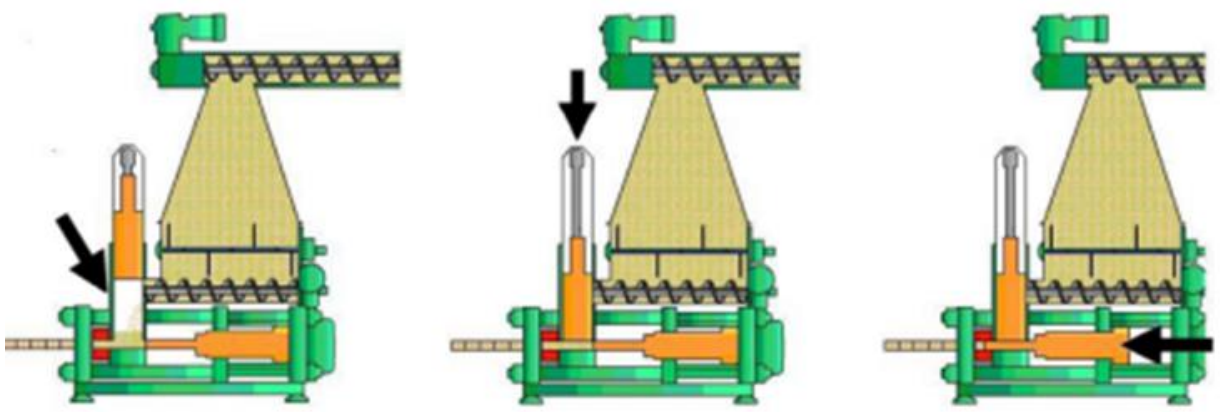

Figure 5. Schema for Hydraulic Press (Solano et al., 2016)

e. Roller Press feedstock falls in between two rollers, rotating in opposite directions, and is compacted into pillow-shaped briquettes (Figure 6). Requires binder in briquetting process and the machine can be used for biomass that is carbonized (Maninder et al., 2012). While pelletizing is similar to briquettes, however, it is smaller in size, approximately $30 \mathrm{~mm}$ (Maninder et al., 2012). Hand molded compaction is the process of producing small quantities of briquettes using hands in molding. It requires sun drying or curing furnaces to form strong briquettes (Kaur et al., 2017)

In addition, according to Essien and Oke (2019), a study that identified the required compaction pressure of various agricultural waste such as sawdust/ palm kernel shell, sawdust/rice husk, and palm kernel shell/rice husk, have obtained results of 715-950 for sawdust/palm kernel shell briquettes, 710-906 for sawdust/rice husk briquettes, and 936-975 for palm kernel shell/rice husk briquettes. The study concluded that identifying the optimum compaction pressure is required to produce good quality briquettes.

f. Manual Press (Figure 7)- it is in the form of piston and screw press but operated with bare hands. Uses minimal pressure, requires binder addition, has a low initial cost, low operating cost, and low skill required in operating compared to other technology, however, it has a low production capacity of about $5 \mathrm{~kg} / \mathrm{h}$ or $50 \mathrm{~kg}$ in a $10 \mathrm{~h} /$ day (Kpalo et al. (2020). Table 2 shows the comparison of some characteristics of screw press, roller press, and piston press.

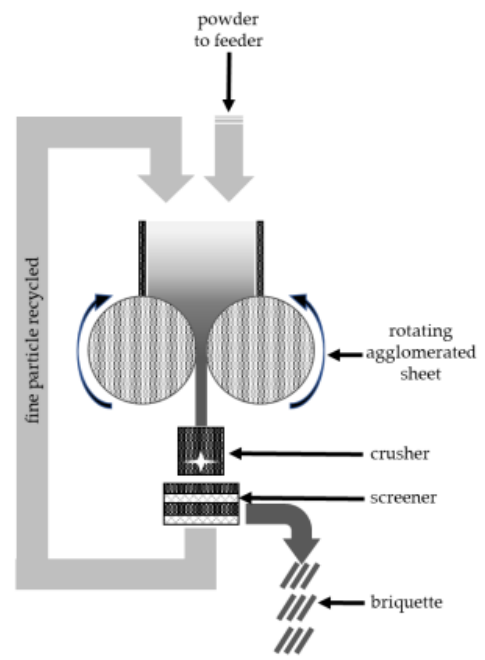

Figure 6. Roller press (Kpalo et al, 2020) 


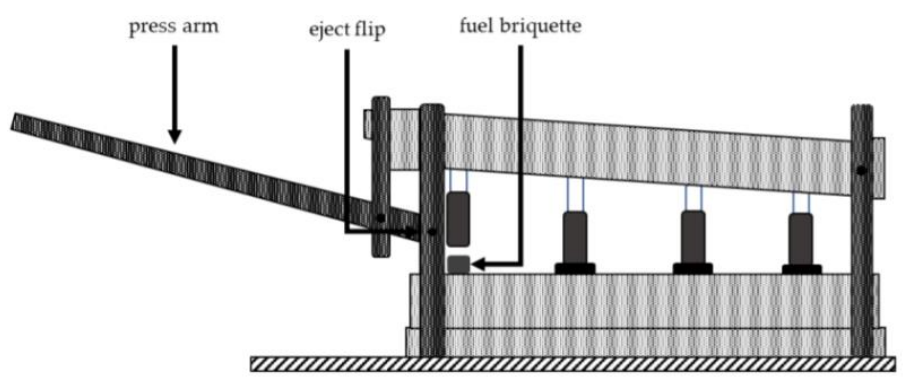

Figure 7. Manual Press (Kpalo et al.,2020)

Table 2. The difference between screw press, roller press, piston press

\begin{tabular}{|c|c|c|c|}
\hline & Screw Press & Roller Press & $\begin{array}{l}\text { Piston Press } \\
\text { (Hydraulic/Mechanical) }\end{array}$ \\
\hline Optimum Moisture Content of raw material (\%) & $4-8$ & $10-15$ & $10-15$ \\
\hline Particle size required $(\mathrm{mm})$ & 2.6 & Less than 4 & $6-12$ \\
\hline Shape & Cylindrical & $\begin{array}{l}\text { Generally, elliptical (depends on } \\
\text { the shape of the die) }\end{array}$ & Cylindrical \\
\hline Bulk Density $\left(\mathrm{g} / \mathrm{cm}^{3}\right)$ & $0.5-0.6$ & $0.48-0.53$ & $0.4-0.5$ \\
\hline Combustion Performance of briquettes & Very Good & Moderate & Moderate \\
\hline
\end{tabular}
Source: Kpalo et al. (2020)

\subsection{Shaping and Sizing}

During the production process, bio-briquettes are molded into different sizes and shapes depending on the manufacturer and the type of molder used. Briquettes can be formed into solid cylindrical, cylindrical with holes, cubic, or prismatic (Solano et al., 2016) as shown in Figure 8. While the commonly shaped prepared in Nepal is a circular one with holes in the middle called bee-hive briquette which is related to how it looks (Rijal $\&$ Sapkota, 2017). According to numerous studies, briquettes are made with holes to provide better combustion characteristics due to its larger specific area (Solano et al.,2016; Kaur et al. 2017). In addition, smaller dimensions provide better and faster combustion because of having a larger specific surface area for reaction (Saptoadi, 2008).

\section{Bio-Briquetting Methods}

Bio-briquetting is the process of densifying biomass such as Agricultural wastes into uniformly shaped briquettes to produce high bulk density which is conveniently used as biofuel (Maninder et al., 2012) and for easy utilization, transportation and storage (El-Haggar, 2005). Each biomass has different composition thus requires different methods to process.

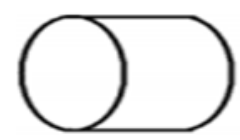

a.) Solid Cylindrical

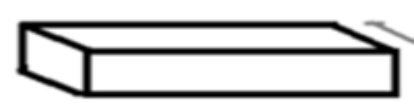

c.) Prismatic
According to Maninder et al. (2012), there are three methods in bio-briquette processing namely (i) Pyrolyzed densification using a binder, (ii) Direct densification of biomass using binders, and (iii) Binderless briquetting.

\subsection{Pyrolyzed Densification using binder}

This briquette production method follows the pattern of pyrolyzing first the biomass then mixing it with binder before densifying. There are existing studies that followed this kind of method in producing, characterizing, and evaluating biobriquettes derived from various agricultural wastes which are presented in Table 3. For instance, Haryati et al. (2018) studied the briquette's quality produced from Durian peel and Bagasse after being terrified from $200-350^{\circ} \mathrm{C}$. Researchers found that the maximum caloric value of durian peel was achieved at $350^{\circ} \mathrm{C}$ temperature with $6,157 \mathrm{cal} / \mathrm{g}$ which was higher than the value obtained in bagasse having 6,109 cal/g. The values obtained are said to be within the caloric value range of subbituminous coal (4,900-6,800 cal/g); while the study of Irhamni et al. (2019) resulted in a $5040 \mathrm{cal} / \mathrm{g}$ caloric value with a 55 minute flame test for Durian Peel bio-briquette that undergone a $400^{\circ} \mathrm{C}$ carbonization. Hence, they have concluded that the value has reached the fuel standards for households.

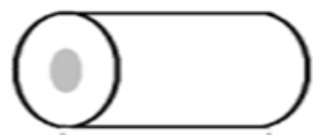

b.) Cylindrical with holes

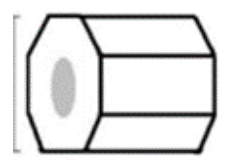

d.) Octagonal

Figure 8. Different Shapes of Briquettes Source: (Solano et al., 2016) 
Additionally, according to Lubwama and Yiga (2018), the carbonization process produces briquettes that adsorb less moisture which is essential to increase its shelf life and storage by preventing it from rotting and decomposing. The researchers further stated, after characterizing the briquettes from rice and coffee husk, that all developed carbonized briquettes resulted in higher fixed carbon percentage, low moisture content, and volatile matter compared to their raw materials which are indicators of good quality products.

\subsection{Direct Densification with Binders}

The densification process predominantly involves two parts; (1) the compaction of materials to increase its density and (2) to conglomerate the material so that the product will remain compressed and not easily deform at a steady state. The resulting product of this process is called briquettes. The process can help raise the calorific value of the material by means of reducing its volatile matter and becomes a stable fuel that is easy to transport and store while still reducing emissions (Kaur et al., 2017).

The densification of loose biomass wastes and other cellulosic materials is concerned with increasing the density of biomass wastes to just about $1000-1200 \mathrm{~kg} / \mathrm{m}^{3}$ and bringing down its volume by 8-10 times (Wakchaure \& Mani, 2009; Obi et al., 2016).

In addition, bio-briquettes use a binder agent or "binder" which can be a partially decomposed fibrous organic material in order to release the fiber needed to physically hold the briquettes together. Briquettes provide various advantages and disadvantages, and one difficulty faced in briquette production is its high cost to compete with the existing wood fuel in many places. Moreover, some process parameters include the applied pressure, pressing time, and the use of heating and binders (Chen et al., 2015).

\subsubsection{Necessity of binding material for densification}

The characteristics of the briquette made from rice straw can be improved using different types of binders such as rice bran, sawdust, soybean residue, sewage sludge in hot densification, seed cake in wet densification (Rezvani et al., 2013; Chou et al., 2009; Talukdar et al., 2014; Saikia \& Baruah, 2013). The availability, cost, and competitive value of the binding material need to be evaluated before using it in the densification process because the raw material cost has the highest share $76.5 \%$ in piston-press briquetting (Stolarski et al., 2013). Other types of binding materials have been used in biomass briquetting such as cassava paste, paper pulp, waste paper pulp, molasses, dry cow dung, clay, asphalt and starch (Madhava et al., 2012; Ngusale et al., 2014; Ugwu \& Agbo, 2013). The compressive strength, compaction ratio and hydrophobic nature of the densified products are higher for inorganic binders compared to organic binders. However, the addition of inorganic binders increases ash content and burn-out temperature and reduces the heating value of the densified products (Ngusale et al., 2014; Hu et al., 2015).

Table 4 shows some literature that underwent direct densification with an additional binder. It illustrates the binder used in briquette production as well as its particle size, pressure added, densification temperature and the resulting quality of bio-briquettes in terms of its proximate parameters (ash content, density, fixed carbon, higher heating value, moisture content, and volatile matter). The studies presented include the study of Mitan and Muhammad (2019) that focused on

Table 3. Some Agricultural wastes that undergo Pyrolization Densification using binder

\begin{tabular}{|c|c|c|c|c|c|c|c|c|}
\hline \multirow{2}{*}{$\begin{array}{l}\text { Agricultural } \\
\text { Waste }\end{array}$} & \multirow{2}{*}{$\begin{array}{l}\text { Added } \\
\text { Biomass } \\
\text { Mixture } \\
\end{array}$} & \multirow{2}{*}{$\begin{array}{l}\text { Binder } \\
\text { Used }\end{array}$} & \multirow{2}{*}{$\begin{array}{l}\text { Binder } \\
\text { Composit } \\
\text { ion }\end{array}$} & \multirow{2}{*}{$\begin{array}{l}\text { Particles } \\
\text { Size }\end{array}$} & \multirow{2}{*}{$\begin{array}{l}\text { Pyrolization } \\
\text { Temp. } \\
\left({ }^{\circ} \mathrm{C}\right)\end{array}$} & \multicolumn{2}{|l|}{ Quality } & \multirow[t]{2}{*}{ Source } \\
\hline & & & & & & Parameters & Value & \\
\hline \multirow[t]{4}{*}{ Durian Shell } & \multirow[t]{4}{*}{-} & \multirow{4}{*}{$\begin{array}{l}\text { Janeng } \\
\text { Starch } \\
\text { with } \\
\text { water }\end{array}$} & \multirow[t]{4}{*}{$2: 1$} & \multirow[t]{4}{*}{8 mesh } & \multirow[t]{4}{*}{400} & Ash content & $7.7 \%$ & \multirow{4}{*}{$\begin{array}{l}\text { (Irhamni et } \\
\text { al., 2019) }\end{array}$} \\
\hline & & & & & & Heating Values & $\begin{array}{l}5040 \\
\text { heat/g }\end{array}$ & \\
\hline & & & & & & Flame test & $55 \mathrm{~min}$. & \\
\hline & & & & & & \multicolumn{2}{|c|}{$\begin{array}{l}\text { no smoke at the beginning } \\
\text { of combustion }\end{array}$} & \\
\hline $\begin{array}{l}\text { Nutmeg Seed } \\
\text { Shells }\end{array}$ & - & - & $30 \%$ & 20 mesh & 350 & \multicolumn{2}{|c|}{$\begin{array}{l}\text { Shatter index at } 350^{\circ} \mathrm{C} \text { is } \\
\text { higher compared } 400^{\circ} \mathrm{C} \\
\text { and } 450^{\circ} \mathrm{C}\end{array}$} & $\begin{array}{l}\text { (Idris et al., } \\
\text { 2018) }\end{array}$ \\
\hline \multirow[t]{3}{*}{ Durian Peel } & $\begin{array}{l}\text { Coconut } \\
\text { Shells }\end{array}$ & Starch & $10 \%$ & 60 mesh & 300 & $\begin{array}{l}\text { Compression } \\
\text { strength }\end{array}$ & $\begin{array}{l}12.70 \\
\mathrm{~g} / \mathrm{cm}^{2}\end{array}$ & \multirow[t]{3}{*}{$\begin{array}{l}\text { (Sari et al., } \\
\text { 2018) }\end{array}$} \\
\hline & palm shells & $\begin{array}{l}\text { Banana } \\
\text { peel }\end{array}$ & $10 \%$ & 60 mesh & 400 & $\begin{array}{l}\text { Compression } \\
\text { strength }\end{array}$ & $\begin{array}{l}11.73 \\
\mathrm{~g} / \mathrm{cm}^{2}\end{array}$ & \\
\hline & $\begin{array}{l}\text { Coconut } \\
\text { Shells }\end{array}$ & $\begin{array}{l}\text { Banana } \\
\text { peel }\end{array}$ & $10 \%$ & 60 mesh & 400 & Caloric Value & $\begin{array}{l}6040 \\
\mathrm{cal} / \mathrm{g}\end{array}$ & \\
\hline \multirow[t]{2}{*}{ Durian Peel } & \multirow[t]{2}{*}{-} & \multirow[t]{2}{*}{$\begin{array}{l}\text { Tapioca } \\
\text { Glue }\end{array}$} & \multirow[t]{2}{*}{-} & \multirow[t]{2}{*}{-} & \multirow[t]{2}{*}{350} & Caloric Value & $\begin{array}{l}6,157 \\
\mathrm{cal} / \mathrm{g}\end{array}$ & \multirow[t]{3}{*}{$\begin{array}{l}\text { (Haryati et al., } \\
\text { 2018) }\end{array}$} \\
\hline & & & & & & $\begin{array}{l}\text { Combustion } \\
\text { Rate }\end{array}$ & $\begin{array}{l}0.0398 \\
\mathrm{~g} / \mathrm{s} .\end{array}$ & \\
\hline Bagasse & - & $\begin{array}{l}\text { Tapioca } \\
\text { Glue }\end{array}$ & - & - & 350 & Caloric Value & $\begin{array}{l}6,109 \\
\mathrm{cal} / \mathrm{g}\end{array}$ & \\
\hline \multirow{4}{*}{$\begin{array}{l}\text { Sugarcane } \\
\text { Bagasse and } \\
\text { leaves }\end{array}$} & \multirow[t]{4}{*}{-} & \multirow{4}{*}{$\begin{array}{l}\text { Lignin } \\
\text { bagasse } \\
\text { and } \\
\mathrm{NaOH}\end{array}$} & $10 \%$ & 30 mesh & - & Caloric Value & $\begin{array}{l}4860 \\
\mathrm{cal} / \mathrm{kg}\end{array}$ & \multirow[t]{4}{*}{$\begin{array}{l}\text { (Saputro et } \\
\text { al., 2020) }\end{array}$} \\
\hline & & & $10 \%$ & 30 mesh & & $\begin{array}{l}\text { Moisture } \\
\text { content }\end{array}$ & $\begin{array}{l}0.0781 \\
\% \\
\end{array}$ & \\
\hline & & & $25 \%$ & 30 mesh & & Caloric Value & $\begin{array}{l}5876 \\
\mathrm{cal} / \mathrm{kg}\end{array}$ & \\
\hline & & & $25 \%$ & 30 mesh & & $\begin{array}{l}\text { Moisture } \\
\text { content }\end{array}$ & $0.139 \%$ & \\
\hline
\end{tabular}


Table 4. Example of bio-briquettes through densification using binder agent

\begin{tabular}{|c|c|c|c|c|c|c|c|}
\hline \multirow{2}{*}{$\begin{array}{l}\text { Agricultural } \\
\text { Waste }\end{array}$} & \multirow{2}{*}{$\begin{array}{l}\text { Binder } \\
\text { Used }\end{array}$} & \multirow{2}{*}{$\begin{array}{l}\text { Particle } \\
\text { Size }\end{array}$} & \multirow{2}{*}{$\begin{array}{l}\text { Pressure } \\
\text { Added }\end{array}$} & \multirow{2}{*}{$\begin{array}{l}\text { Densification } \\
\text { Temperature }\end{array}$} & \multicolumn{2}{|l|}{ Quality } & \multirow[b]{2}{*}{ Source } \\
\hline & & & & & Parameters & Value & \\
\hline \multirow[t]{5}{*}{ Banana peels } & \multirow[t]{5}{*}{ Molasses } & \multirow{5}{*}{$\begin{array}{l}35 \mathrm{~mm} \text { of } \\
\text { inner } \\
\text { diameter } \\
\text { and } \\
10 \mathrm{~mm} \text { of } \\
\text { thickness }\end{array}$} & \multirow[t]{5}{*}{3 to $11 \mathrm{MPa}$} & \multirow{5}{*}{$\begin{array}{l}270,370 \text { and } \\
470^{\circ} \mathrm{C} \text { with } \\
\text { heating rate if } \\
10^{\circ} \mathrm{C} / \mathrm{m} \text { for } 60 \\
\mathrm{~min} .\end{array}$} & Ash content & $\begin{array}{l}20.59 \text { to } \\
30.03 \%\end{array}$ & \multirow{5}{*}{$\begin{array}{l}\text { (Mitan \& } \\
\text { Muhammad } \\
\text {, 2019) }\end{array}$} \\
\hline & & & & & Fixed carbon & $\begin{array}{l}2.00 \text { to } \\
3.80 \%\end{array}$ & \\
\hline & & & & & Moisture Content & $\begin{array}{l}5.00 \text { to } \\
6.06 \%\end{array}$ & \\
\hline & & & & & Volatile Matter & $\begin{array}{l}61.91 \\
\text { to } \\
70.15 \%\end{array}$ & \\
\hline & & & & & $\begin{array}{l}\text { Higher Heating Value } \\
\text { (HHV) }\end{array}$ & $\begin{array}{l}13.70 \text { and } \\
17.10 \\
\mathrm{MJ} / \mathrm{kg} \\
\text { respectiv } \\
\text { ely }\end{array}$ & \\
\hline \multirow[t]{6}{*}{ Cassava waste } & \multirow[t]{6}{*}{ Starch } & \multirow[t]{6}{*}{$1.19 \mathrm{~mm}$} & \multirow[t]{6}{*}{$204 \mathrm{MPa}$} & \multirow[t]{6}{*}{$120^{\circ} \mathrm{C}$} & Ash content & $14.45 \%$ & \multirow{6}{*}{$\begin{array}{l}\text { (Granado et } \\
\text { al., 2021) }\end{array}$} \\
\hline & & & & & Fixed Carbon & $13.10 \%$ & \\
\hline & & & & & Moisture Content & $12 \%$ & \\
\hline & & & & & Volatile Matter & $72.50 \%$ & \\
\hline & & & & & $\begin{array}{l}\text { Higher Heating Value } \\
\text { (HHV) }\end{array}$ & $17.12 \%$ & \\
\hline & & & & & Energy density & $\begin{array}{l}15.7 \\
\mathrm{GJ} / \mathrm{m}^{3}\end{array}$ & \\
\hline \multirow[t]{5}{*}{ Rice straw } & \multirow[t]{5}{*}{ Sawdust } & \multirow[t]{5}{*}{$\begin{array}{l}<2.5 \mathrm{~mm} \text { or } \\
0.1-150 \\
\mathrm{~mm}\end{array}$} & \multirow[t]{5}{*}{$\geq 27.6 \mathrm{MPa}$} & \multirow[t]{5}{*}{---} & Ash content & $\begin{array}{l}13.61 \% \\
\text { to } 10.3 \% \\
\text { and } \\
6.93 \% \text {, } \\
\text { respectiv } \\
\text { ely }\end{array}$ & \multirow[t]{5}{*}{$\begin{array}{l}\text { (Rahaman } \\
\text { \& Salam, } \\
\text { 2017) }\end{array}$} \\
\hline & & & & & Stable density & $\begin{array}{l}>600 \\
\mathrm{~kg} / \mathrm{m}^{3}\end{array}$ & \\
\hline & & & & & Moisture Content & $10.3 \%$ & \\
\hline & & & & & Volatile Matter & $74.68 \%$ & \\
\hline & & & & & $\begin{array}{l}\text { Higher Heating Value } \\
\text { (HHV) }\end{array}$ & $7.2 \%$ & \\
\hline
\end{tabular}

temperature effect on the densification of banana peels briquette using molasses as a binder. The study aimed to observe the effect of temperature during carbonization of banana peels and its impact on banana peel densification to produce a high quality briquette; Granado et al. (2021), studied the effects of pressure densification on the strength and properties of cassava waste briquettes that utilized starch as a binder. The study analyzed the effects of pressure densification on the properties of cassava residue briquettes, especially on the strength of the briquettes. It used three compaction pressures such as 102,153, and $204 \mathrm{MPa}$ and three pressing hold times: without holding pressure time, $60 \mathrm{~s}$, and $120 \mathrm{~s}$, to produce briquettes without heating and verify their formation concerning the compaction; and while for Rahaman and Salam (2017), the study focused on the characterization of cold densified rice straw briquettes and the potential use of sawdust as a binder. Furthermore, the study investigated the effect of particle size, pressure, and mold diameter on the physical characteristics of rice straw briquettes. The briquettes were prepared utilizing a manually operated piston-press cold densification system and analyzed in terms of initial density, stable density, density ratio, compaction ratio, percentage of volume change, shatter index, and energy consumption.

\subsection{Binderless Briquetting}

Binderless briquetting produces briquettes that are either pyrolized or directly densified without the help of binder due to the natural lignin component of lignocellulosic plants that acts as a glue to bond the cellulose fibers (Oladeji, 2015). The method uses high compaction pressure to densify. According to Kaur et al., (2017), the application of high pressure on the biomass increases the mechanical interlocking and increases adhesion/cohesion forces leading to the formation of intermolecular bonds in the contact area. Some studies that use the binderless method include Gurdil and Demirel (2018), who studied hazelnut, corn and sunflower residue for briquette production and found that under the compression pressure of $160 \mathrm{MPa}$, the briquettes made from the three stated agricultural wastes have higher tumbler indexes compared to briquettes with compression pressure of $80 \mathrm{MPa}$. While hazelnut husks obtained the lowest tumbler index because of its less fibrous characteristic compared to corn and sunflower.

Furthermore, Alchalil et al. (2021) studied the characteristics of bio-briquettes made from rice husk and coffee pulp at pressure 100,150 , and 200 . The study samples used were rice husk that underwent carbonization and coffee pulp that were directly densified and the mixture of both agricultural wastes. The researchers have obtained a caloric value of 4764 cal/g using a $100 \%$ coffee skin briquette with 16.5 wt.\% of moisture, $12 \mathrm{wt} . \%$ ash content, and combustion rate of $0.019 \mathrm{~g} / \mathrm{s}$ with an ignition time of 196 seconds. Furthermore, the study observed that there is no increase in combustion rate as briquetting pressure applied increases. Figure 9 illustrates the basic process of briquettes production while Figure 10 shows an example of the produced briquettes under low-pressure carbonization and non-carbonized under high-pressure densification. 


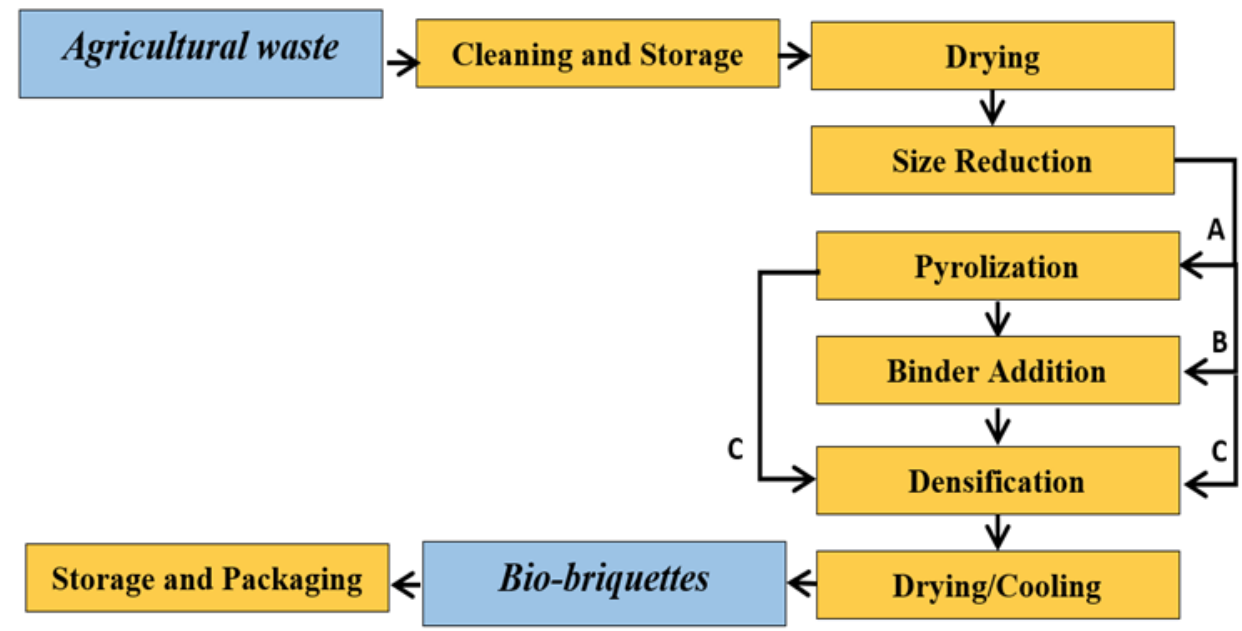

Figure 9. The basic process diagram of bio-briquette production
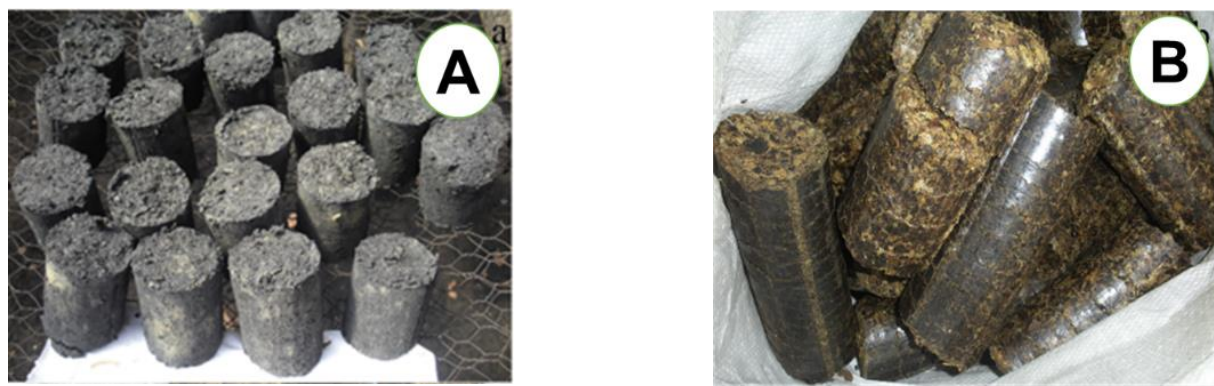

Figure 10. (a) Samples of briquettes developed under low pressure after carbonization and (b) non- carbonized under high pressure development. Source: (Lubwama \& Yiga, 2018)

\section{Bio-Briquette Quality Testing}

The safe and sound disposal of agricultural waste is a major concern of every country today. Agricultural wastes are being produced in millions of tons in both urban and rural areas, which are often deposited in dumpsites, left untreated, or burned in open fires. A potential remedy for these wastes disposal and high fuel dependence on wood as fuel is the conversion of this biomass into high-density briquettes. The quality of briquettes is dependent on the raw materials and the briquetting process. Combustion and environmental safety are dependent mostly on the nature of the raw material. This nature includes the structure (e.g., size, fibrous, non-fibrous, etc.), chemical (e.g., lignin-cellulose content), physical (e.g., material particle size, density, and moisture content), and purity (e.g., trace of element (sulfur), etc.). Combustion is measured by parameters such as calorific value, moisture content, volatile matter, and ash content, while environmental concern is measured by the toxic emissions during combustion. The briquetting process, on the other hand, determines the durability and stability of briquettes. Furthermore, compressive strength, abrasion resistance, impact resistance, moisture absorption, and density are the parameters that determine durability and stability. They are considered the most important quality parameters of densified biomass (Gilvari et al., 2019). The quality of briquettes is characterized in terms of physical, mechanical, chemical, and thermal properties, depending on the measured parameters. It is also indicative of the effectiveness of the densification process and influences their ability to endure certain impacts because of handling, storage, and transportation.

\subsection{Briquette Quality Tests}

A. Moisture content (MC). Defined as the ratio of the mass of water in a sample of briquette before and after drying, expressed as a percentage. MC affects the combustion process where the heat produced will be used to evaporate the water first (Suryaningsih et al., 2018). Furthermore, moisture content analysis involved a series of repeating the process of drying and weighing via a specific procedure. The moisture content was determined using Equation 1 from (Onuegbu et al., 2010).

$$
\% \mathrm{MC}=\left(\frac{\mathrm{m}_{\mathrm{b}}-\mathrm{m}_{\mathrm{a}}}{\mathrm{m}_{\mathrm{b}}}\right) * 100 \%
$$

Where $m_{b}$ is the mass of briquette immediately after compression and $m_{a}$ is the mass of briquette after drying in still air.

B. Ash content (AC). Defined as the mass of incombustible material remaining after burning a given briquette sample, expressed as a percentage. According to SNI No. $1 / 6235 / 2000$ standard, the moisture content and ash content should be less than $8 \%$ and the volatile matter is less than 15\% (Idris et al., 2018). A higher value of AC shows a lower Caloric Value, the harder it takes to combust. Ash content will be calculated under ASTM D-3174 2012 standard formulas as shown in Equation 2 (Ifa et al., 2020). 


$$
\% \mathrm{AC}=\left(100-\frac{\mathrm{W}_{0}-\mathrm{W}}{\mathrm{W}_{\text {so }}}\right) * 100 \%
$$

Where $W_{o}$ is sample and saucer weight before ashing (g), W is the weight of saucer and ash (g), and $W_{s o}$ is sample weight before ashing $(\mathrm{g})$.

C. Volatile matter content (VM). It is unstable material that tends to not remain in one state and will rapidly transit to another state, or vaporize, expressed as a percentage. It is defined as substances that are lost when the sample is heated in a furnace for 7 minutes at 900 . The higher the volatile content in bio-briquettes, the easier it combusts (Suryaningsih et al., 2017; Suryaningsih et al., 2018; Ifa et al.,2020). A high value of volatile matter can degrade briquette's quality because it lowers the content of fixed carbon, can also affect the calorific value produced and causes in increasing the amount of smoke produced from burning (Idris et al., 2018). VM can be calculated using ASTM D-3175 2018 standard with the following formula Equation 3 and Equation 4.

$$
\% \text { Lost weight }=\mathrm{A}=\left(\frac{\mathrm{W}_{0}-\mathrm{W}}{\mathrm{W}_{\mathrm{SO}}}\right) * 100 \%
$$

$$
\% \mathrm{VM}=\text { Lost weight }- \text { Moisture Content } * 100 \%
$$

Where $\mathrm{W}_{0}$ is sample weight and initial cup (g), $\mathrm{W}$ is the weight of cup and ash after heating $(\mathrm{g})$, and $\mathrm{W}_{\mathrm{SO}}$ is the initial sample weight $(\mathrm{g})$.

D. Fixed carbon (FC). It is defined as the level of bonded carbon contained in the briquettes, expressed as a percentage. The fixed carbon is the result of a reduction of $100 \%$ sample with the volatile matter, moisture content, and ash content. A higher level of carbon bound leads to an increase in its calorific value (Suryaningsih et al., 2018; Ifa et al., 2020). The fixed carbon (FC) was determined using the data previously obtained in the proximate analysis $(\mathrm{MC}, \mathrm{VM}, \mathrm{AC})$ and can be calculated using the Equation 5 (García et al., 2012). The released moisture content is considered in the volatile matter percentage.

$$
\% \mathrm{FC}=100-(\mathrm{AC}(\%)-\mathrm{VM}(\%))
$$

E. Caloric Value. Caloric value is known as heating value (HV) or energy value of a briquette. It is the amount of heat liberated per unit mass of the briquette and is measured using a bomb calorimeter. The calorific value shows the energy contained in a briquette. It is determined by measuring the heat produced by the complete combustion of a specified quantity of it, expressed in calories per gram. This test was conducted to determine the standard quality of the briquettes' fuel power and determine the standard sale value of the briquettes (Suryaningsih et al., 2018). Calorific values will be calculated using the fixed carbon content and volatile matter of the briquettes according to the method and Equation 6 presented in (Adetogun et al., 2014).

$$
\mathrm{HV}=(\mathrm{FC} \%+\mathrm{VM} \%) \mathrm{kJ} / \mathrm{kg}
$$

Where HV is the calorific value, $\mathrm{FC}$ is the percentage of fixed carbon content, and VM is the percentage of volatile matter.

Table 5 presents the list of bio-briquettes made from agricultural waste and their values obtained after proximate analysis. According to Suryaningsih et al. (2018), other briquette characterizations that are essential for packaging design and transportation handling include mass density and compressive strength.

F. Mass Density. The mass density of a briquette is equal to mass per unit volume of the briquette and can be calculated using Equation 7:

$$
\rho=\left(\frac{\mathrm{m}}{\mathrm{V}}\right) ; \frac{\mathrm{kg}}{\mathrm{cm}^{3}}
$$

Where $\rho$ is density of briquette $\left(\frac{\mathrm{kg}}{\mathrm{cm}^{3}}\right), m$ is weight of briquette $(\mathrm{kg})$ and $V$ is volume of briquette $\left(\mathrm{cm}^{3}\right)$.

G. Compressive Strength Test. The compressive strength test is defined as a mechanical test that measures the maximum amount of compressive load a briquette can bear before fracturing and can be calculated using Equation 8 . Moreover, Figure 11 presents an example of a briquette undergoing a Compressive Strength Test.

$$
\mathrm{K}^{\mathrm{t}}=\left(\frac{\mathrm{P}}{\mathrm{A}}\right) ; \frac{\mathrm{kg}}{\mathrm{cm}^{2}}
$$

\section{$[8]$}

Where: $\mathrm{K}^{\mathrm{t}}$ is stress at failure $\left(\frac{\mathrm{kg}}{\mathrm{cm}^{2}}\right), P$ is axial load at failure $(\mathrm{kg})$ and $A$ is cross-sectional area $\left(\mathrm{cm}^{2}\right)$.
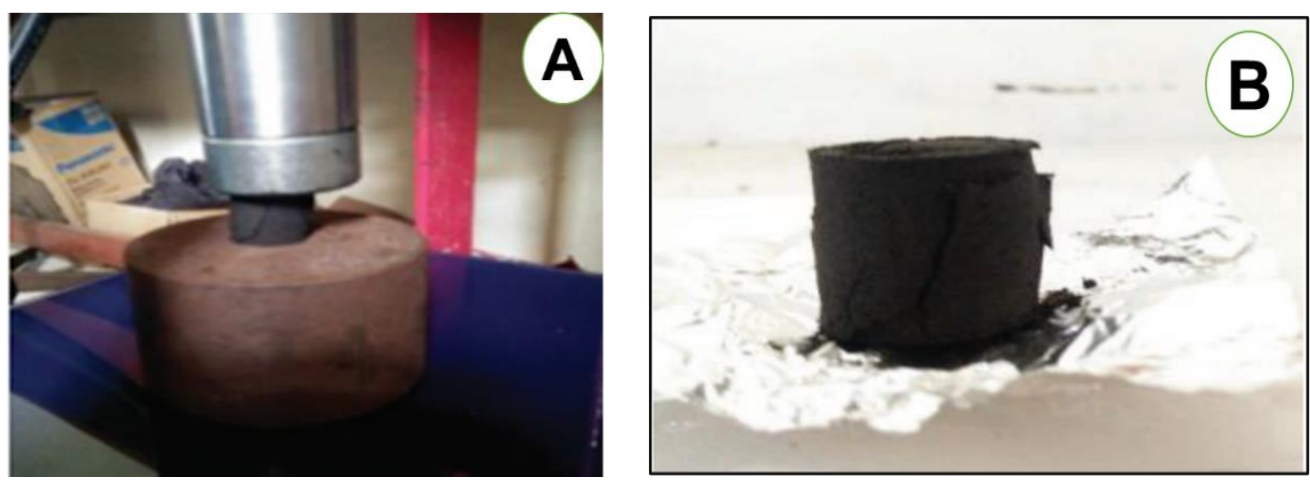

Figure 11. (a) Compressive strength test, (b) Compressive strength result. Source: (Suryaningsih et al., 2018) 
Moreover, Table 6 presents the list of the quality indicators used in briquette production utilizing the three (3) methods discussed and reviewed above. It indicates several agricultural wastes that measure different proximate parameters and other quality indicators of briquette.

Table 5. Proximate and heating values of bio-briquettes from various agricultural materials

\begin{tabular}{|c|c|c|c|c|c|c|}
\hline Material & $\begin{array}{l}\text { Moisture } \\
\text { (wt\%) }\end{array}$ & Ash (wt\%) & $\begin{array}{l}\text { Volatile Matter } \\
(w \mathrm{t} \%)\end{array}$ & $\begin{array}{l}\text { Fixed } \\
\text { carbon } \\
\text { (wt\%) }\end{array}$ & $\begin{array}{l}\text { Calorific value } \\
(\mathrm{MJ} / \mathrm{kg})\end{array}$ & Source \\
\hline Cashew nut waste & 5.30 & 4.96 & 17.16 & 72.62 & 29.49 & (Ifa et al., 2019) \\
\hline $\begin{array}{l}\text { Banana peels, corn } \\
\text { cobs, and Coal mixture }\end{array}$ & 5.14 & 6.06 & 26.18 & 62.62 & 26.36 & (Faizal, 2017) \\
\hline $\begin{array}{l}\text { Bagasse and corn } \\
\text { starch waste }\end{array}$ & 6.86 & 8.59 & 48.50 & 42.92 & 10.30 & $\begin{array}{l}\text { (Zanella et al., } \\
\text { 2016) }\end{array}$ \\
\hline Banana leaves & 7.17 & 10.70 & 75.3 & 14,00 & 17.70 & $\begin{array}{l}\text { (Maia et al., } \\
\text { 2014) }\end{array}$ \\
\hline Banana tree waste & $11.0 \%-19.3 \%$ & $3.3 \%-11.7 \%$ & $75.8 \%-94.7 \%$ & - & - & $\begin{array}{l}\text { (Ahmad et al., } \\
\text { 2018) }\end{array}$ \\
\hline $\begin{array}{l}\text { The mixture of bagasse } \\
\text { and coffee husk }\end{array}$ & 4.40 & 12.00 & 24.00 & 64.00 & 11.13 & $\begin{array}{l}\text { (Pallavi et al., } \\
\text { 2013) }\end{array}$ \\
\hline Bagasse & 4.10 & 36.4 & 27.20 & 36.40 & 18.38 & $\begin{array}{l}\text { (Onchieku et al., } \\
\text { 2012) }\end{array}$ \\
\hline Hazelnut Shell & -- & 7.00 & 72.00 & 21.00 & 18.89 & $\begin{array}{l}\text { (Haykiri-Acma } \\
\text { \& Yaman, 2010) }\end{array}$ \\
\hline Durian peel & 0.01 & 18.18 & 3.94 & 77.87 & 6,274.29 kcal / kg & $\begin{array}{l}\text { (Nuriana et al., } \\
\text { 2014) }\end{array}$ \\
\hline
\end{tabular}

Note: wt\% - Percentage by weight

Table 6. List of Quality Indicators used in Briquette Production

\begin{tabular}{|c|c|c|c|c|}
\hline Agricultural wastes & $\begin{array}{l}\text { Method of Briquette } \\
\text { Production }\end{array}$ & Proximate Analysis & Other Quality Indicators & Source \\
\hline $\begin{array}{l}\text { Bamboo fiber and } \\
\text { Sugarcane Skin }\end{array}$ & Binderless Briquetting & $\begin{array}{l}\text { Moisture content, ash } \\
\text { content, gross and net } \\
\text { caloric value and } \\
\text { elementary composition } \\
\text { (carbon hydrogen, } \\
\text { nitrogen, sulfur, oxygen) }\end{array}$ & $\begin{array}{l}\text { Bulk density, Mechanical } \\
\text { durability, Rupture Force }\end{array}$ & $\begin{array}{l}\text { (Brunerová et } \\
\text { al., 2018) }\end{array}$ \\
\hline $\begin{array}{l}\text { Rice husk and Coffee } \\
\text { Husk }\end{array}$ & $\begin{array}{l}\text { Pyrolyzed Densification } \\
\text { using binder and Binderless } \\
\text { Briquetting }\end{array}$ & $\begin{array}{l}\text { Moisture content, volatile } \\
\text { matter, caloric value, ash } \\
\text { content, fixed carbon }\end{array}$ & $\begin{array}{l}\text { Drop Test and Water } \\
\text { Boiling test }\end{array}$ & $\begin{array}{l}\text { (Lubwama \& } \\
\text { Yiga, 2018) }\end{array}$ \\
\hline Rice husk and Bran & $\begin{array}{l}\text { Direct Densification with } \\
\text { Binders }\end{array}$ & $\begin{array}{l}\text { Moisture content, } \\
\text { caloric value }\end{array}$ & $\begin{array}{l}\text { Compressive strength } \\
\text { Durability, Density }\end{array}$ & $\begin{array}{l}\text { (Yank et al., } \\
\text { 2016) }\end{array}$ \\
\hline $\begin{array}{l}\text { Sugarcane leaves and } \\
\text { sugarcane bagasse }\end{array}$ & $\begin{array}{l}\text { Pyrolyzed Densification } \\
\text { using binder }\end{array}$ & $\begin{array}{l}\text { Caloric value and moisture } \\
\text { content }\end{array}$ & - & $\begin{array}{l}\text { (Saputro et al., } \\
\text { 2020) }\end{array}$ \\
\hline Nutmeg Seed Shells & $\begin{array}{l}\text { Pyrolyzed Densification } \\
\text { using binder }\end{array}$ & $\begin{array}{l}\text { Calorific value, moisture } \\
\text { content, volatile matter, } \\
\text { fixed carbon, ash content }\end{array}$ & $\begin{array}{l}\text { Analysis of gas content } \\
\text { Shatter indexes test }\end{array}$ & $\begin{array}{l}\text { (Idris et al., } \\
\text { 2018) }\end{array}$ \\
\hline Cashew nutshell waste & $\begin{array}{l}\text { Pyrolyzed Densification } \\
\text { using binder }\end{array}$ & $\begin{array}{l}\text { Moisture content, volatile } \\
\text { matter, fixed carbon, ash } \\
\text { content }\end{array}$ & - & (Ifa et al., 2020) \\
\hline $\begin{array}{l}\text { Durian peel mixed } \\
\text { with Coconut and Palm } \\
\text { Shells }\end{array}$ & $\begin{array}{l}\text { Pyrolyzed Densification } \\
\text { using binder }\end{array}$ & Caloric value, ash content & $\begin{array}{l}\text { Density, Compression } \\
\text { Strength, Porosity, } \\
\text { Burning Time }\end{array}$ & $\begin{array}{l}\text { (Sari et al., } \\
\text { 2018) }\end{array}$ \\
\hline Durian Shell waste & $\begin{array}{l}\text { Pyrolyzed Densification } \\
\text { using binder }\end{array}$ & $\begin{array}{l}\text { Ash content, heating value, } \\
\text { Flame test }\end{array}$ & - & $\begin{array}{l}\text { (Irhamni et al., } \\
\text { 2019) }\end{array}$ \\
\hline $\begin{array}{l}\text { Mustard stalk and } \\
\text { other biomass }\end{array}$ & $\begin{array}{l}\text { Direct Densification with } \\
\text { Binders }\end{array}$ & $\begin{array}{l}\text { Moisture content, bulk } \\
\text { density, caloric value, ash } \\
\text { content }\end{array}$ & $\begin{array}{l}\text { Tumbling resistance, } \\
\text { Shattering resistance, } \\
\text { Resistance to water } \\
\text { penetration }\end{array}$ & $\begin{array}{l}\text { (Wakchaure \& } \\
\text { Mani, 2011) }\end{array}$ \\
\hline $\begin{array}{l}\text { Hazelnut, Corn and } \\
\text { Sunflower Residue }\end{array}$ & Binderless Briquetting & - & Tumbling Test & $\begin{array}{l}\text { (Gurdil \& } \\
\text { Demirel, 2018) }\end{array}$ \\
\hline
\end{tabular}




\section{Challenges and Future Prospects}

In the Philippines, there are myriad natural resources that could be utilized as one of the sources of energy including agricultural wastes converting into high valuable briquettes. The briquetting technology has been dominating in some parts of Asia, America, and Europe. In such advanced nations, successes have been recorded in the production and utilization of briquettes, but the same cannot be compared in most developing countries including the Philippines. The expansion of densification of biomass depends on three factors, which include residue availability, adequate technologies, and the market for briquettes (Felfli et al., 2011). For countries in the developing world, residue availability does not present as a problem. However, the optimization of the chemical and mechanical treatments needed for most of the innumerable feedstocks remains a challenge. On the first hand, the community is lacking funds from the government which is one of the reasons why the availability of briquetting technologies is limited in some parts of the country. For this reason, it will lead to a lack of technology to utilize across the country due to the expense of the cost of the briquette equipment. Production of briquettes on a large scale will require significant capital investment. This presents an obstacle to further expand biomass densification. In addition, some citizens including farmers lack insights into briquettes which they tend to neglect the opportunity of innovating it sustainably. As time passes by, while the population is increasing, the waste and energy consumption are also surmounting. Most individuals consume energy that is convenient for them to use without thinking about the depletion of energy sources. Fabricating briquettes from different kinds of agricultural wastes will merit another source of renewable energy for the greater good. Furthermore, to attract more investment in areas that lack adequate financial capacity and high energy input, efforts should be geared towards the development of more user-friendly and cost and energy-effective technologies at various scales. The market for briquette and its extensive utilization as substitutes to conventional biomass and fossil fuel exists. In conclusion, to bring its full potential to bear, the challenges presented above should be addressed.

The most widely used briquetting technologies are Impact Densification (Piston Briquetting), Extrusion Densification (Screw Briquetting), and Hydraulic or Pneumatic Briquetting, Roller Press, and Manual Press. These technologies differ in terms of particle size and moisture content of raw material needed, final density, molder, energy consumption, etc. (Solano et al., 2016; Kpalo et al., 2020) which affects the cost of the machine. However, for a low initial production cost of briquettes, a Manual press is typically used.

In starting a briquetting production process, it is important to take into consideration the total cost of Briquetting Production including Capital Cost (machine, processing building, etc.), installation cost, operation cost, repair and maintenance cost, and the possible price of biomass wastes in the long run; the amount of biomass available in the vicinity to ensure sustainable production; and the price of the alternative fuels for comparison. The cost of briquettes should be lesser than fossil fuels for it to be called an effective replacement for firewood, coal, and kerosene in cooking (Kpalo et al., 2020).

\section{Summary and conclusion}

In the present, the world is undergoing an increase in energy demand due to the rising population. With the growing concern of climate change because of GHGs produced by fossil/coal fuel, the bio-briquette most specifically from agricultural wastes is a renewable energy that has a strong potential to be an alternative energy resource considering various factors, including the volume and the sustainability of wastes produced within the vicinity, initial cost, machine availability, and many more. It should also be less expensive or more efficient compared to the existing fossil/coal fuel for it to be called an effective replacement, and be able to compete in the market.

Moreover, in bio-briquette processing, it is essential to consider the proper type of method, binder additives and densification machine, particle size, moisture content, the shape of molder, etc. to optimize the quality of briquettes produced from a certain agricultural waste. Understanding the general concept of the production process, the basic quality testing parameters, and other considerations in briquetting paves the way for the development of a successful environmental-friendly, efficient and cost-effective bio-briquettes.

\section{Acknowledgement}

The authors are thankful to the Center for Resource Assessment, Analytics \& Emerging Technologies (CReATe) and the Department of Agricultural and Biosystems Engineering (DABE), Caraga State University for making this study possible.

\section{Author contributions}

Kenneth N. Sindol and Mia Me T. Aspe conducted the literature review and drafted the manuscript. Philip Donald C. Sanchez conceptualized the structure of the manuscript, meticulously and systematically revised the paper based on reviewers' comments and finalized the paper up to publication.

\section{Conflict of interests}

The authors declare that they have no known competing financial interests or personal relationships that could influence the result reported in this review paper.

\section{References}

Adetogun, A.C., Ogunjobi, K.M., \& Are, D.B. (2014). Combustion properties of briquettes produced from maize cob of different particle sizes. Journal of Research in Forestry, Wildlife and Environmental, 6 (1), 28-38. https://libraryguides.vu.edu.au/apareferencing/7JournalArticles

Ahmad, K.K., Sazali, K., \& Kamarolzaman, A.A. (2018). Materials Today: Proceedings, 5 (10) Part 2, 21744-21752. https://doiorg/10.1016/j.matpr.20180.7.027

Alchalil-Setiawan, A., Juwaini, \& Nur, T.B. (2021). Effect of Densification Pressure on Physical and Combustion Properties of Binderless Briquettes Made from Rice-Husk and Coffee-Pulp. Proceedings of the 2nd International Conference on Experimental and Computational Mechanics in Engineering, 1-8. https://doi.org/10.1007/978-981-16-0736-3_1

Bili, A., \& Vagiona, D.G. (2018). Use of multicriteria analysis and GIS for selecting sites for onshore wind farms: The case of Andros Island (Greece). European Journal of Environmental Sciences; 8(1): 5-13. doi: $10.14712 / 23361964.2018 .2$

Bracco,S., Calicioglu,O., San Juan, M. G., \& Flammini, A. (2018). Assessing the contribution of Bioeconomy to the Total Economy: A Review of National Frameworks. Sustainability, $\quad 10 \quad$ (6) , 1698. https://doi.org/10.3390/su10061698

Brunerová, A., Roubík, H., Brožek, M., Herák, D., Šleger,V., \& Mazancová , J. (2017). Potential of Tropical Fruit Waste Biomass for Production of Bio-Briquette Fuel: Using 
Indonesia as an Example. Energies,10 (12), 2119. https://doi.org/10.3390/en10122119

Brunerová, A., Roubík, H., \& Brožek, M. (2018). Bamboo Fiber and Sugarcane Skin as a Bio-Briquette Fuel . Energies, 11 (9), 2186. http://dx.doi.org/10.3390/en11092186

Brožek,M., Nováková,A.,\& Kolářová, M. (2012). Quality evaluation of briquettes made from wood waste. Res. Agr. Eng., 58(1), 30-35. https://doi.org/10.17221/33/2011RAE

Capilla J.A.J, Carrión, J.A., \& Alameda-Hernández, E. (2016). Optimal site selection for upper reservoirs in pump-back systems, using geographical information systems and multicriteria analysis. Renewable Energy, 86:429-440. doi: 10.1016/j.renene.2015.08.035

Chaney, J. O. (2010). Combustion Characteristics of Biomass Briquettes (Doctoral dissertation). http://eprints.nottingham.ac.uk/11732/1/Combustion_ Characteristics_of_Biomass_Briquettes .pdf

Chen, W.H., Peng, J., \& Bi, X.T. (2015). A state-of-the-art review of biomass torrefaction, densification and applications. Renew. Sustain. Energy Rev., 44, 847- 866. https://doi.org/10.1016/j.rser.2014.12.039

Chirchir, D. K., Nyaanga, D. M., \& Githeko, J.M. (2013). Effect of binder types and amount on physical and combustion characteristics. International Journal of Engineering Research Science and Technology, 2 (1),12-20. http://www.ijerst.com/currentissue.php

Chou, C.S., Lin, S.H., \& Lu, W.C. (2009). Preparation and characterization of solid biomass fuel made from rice straw and rice bran. Fuel Processing Technology, 90 (7-8), 980-987. https://doi.org/10.1016/j.fuproc.2009.04.012

Dinesha, P., Kumar, S., \& Rosen, M.A. (2019). Biomass Briquettes as an Alternative Fuel: A Comprehensive Review. Energy Technology, 7 http://dx.doi.org/10.1002/ente.201801011

El-Haggar, S. (2005). Rural and Developing Country Solutions. Environmental Solutions, Chapter 13, 313-400. Academic Press. https://doi.org/10.1016/B978-0120884414/50015-0

Essien, U.A., \& Oke, P.K. (2019). Modelling the effect of compaction pressure on the densification of agricultural waste briquettes. African Journal of Science Technology Innovation and Development, 11(5), 579-588. https://doi.org/10.1080/20421338.2018.1556456

European Commission (2015). EIP-AGRI Workshop "Opportunities for Agriculture and Forestry in the Circular Economy." Workshop Report 28-29 October 2015.

Brussels, Belgium.https://ec.europa.eu/eip/agriculture/sites/agri eip/files/eipagri_ws_circular_economy_final_report_201 5_en.pdf. Accessed on 14th July 2021.

European Commission (2017a). European Bioeconomy Stakeholders .Manifesto https://ec.europa.eu/research/bioeconomy/pdf/europe an_bioeconomy_stakeholders_manifesto.pdf, Accessed on 14th July 2021.

European Commission (2017b). Review of the 2012 European Bioeconomy Strategy. Office of the European Union, Brussels, Belgium. https://doi.org/10.2777/086770.

Fadele, O.K., Amusan ,T.O., Afolabi, A.O., \& Ogunlade C.A. (2021). Characterisation of a briquette from forest wastes: Optimisation approach. Res. Agr. Eng., 67, 138-147. https://doi.org/10.17221/6/2021-RAE

Faizal, M. (2017). Utilization biomass and coal mixture to produce alternative solid fuel for greenhouse gas. Int. J. Adv. Sci. Eng. Inf. Technol., 7 (3), 950-956.

Felfli, F.F., Mesa, P., J.M., Rocha, J.D., Filippetto, D., Luengo, C.A., \& Pippo, W.A. (2011). Biomass briquetting and its perspectives in Brazil. Biomass and Energy, 35(1), 236242. doi.org/10.1016/j.biombioe.2010.08011

Food and Agriculture Organization of the United Nations (FAO) \& Organization for Economic Co-operation and Development (OECD) (2019). Background Notes on Sustainable, Productive and Resilient Agro-Food Systems: Value Chains, Human Capital, and the 2030 Agenda. A Report to the G20 Agriculture Deputies July 2019. https://www.oecd-ilibrary.org/docserver/ Accessed on 8th Jul 2021

Food and Agriculture Organization of the United Nations (FAO) (2017). The Future of Food and Agriculture: Trends and Challenges. http://www.fao.org/3/a-i6881e.pdf, Accessed on agricultural waste. Accessed on 9th July 2021.

García, R., Pizarro, C., Lavín, A.G., \& Bueno, J.L. (2012). Bioresource Technology Characterization of Spanish biomass wastes for energy use. Bioresour. Technol., 103 (1), 249-258.

Gilvari, H., de Jong, W., \& Schott, D.L. (2019). Quality parameters relevant for densification of bio-materials: Measuring methods and affecting factors $-\mathrm{A}$ review. Biomass Bioenergy, 120,117-134.

Granado, M.P.P., Suhogusoff, Y.V.M., Santos, L.R.O., Yamaji, F.M., \& Conti, A.C. (2021). Effects of Pressure densification on strength and properties of cassava waste briquettes. Renewable Energy, 167, 306-312. https://doi.org/10.1016/j.renene.2020.11.087

Gurdil, G.A.K., \& Demirel, B. (2018). Effect of Particle Size on Surface Smoothness of Bio-Briquettes Produced from Agricultural Residues. Manufacturing Technology, 18 (5), 742-747.

Handra, N., Kasim, A., Gunawarman, \& Santosa (2018). Effects of Binders on EFB Bio-briquettes of Fuel Caloric Value. International Journal on Advanced Science Engineering Information Technology, 8(4), 1071-1076. https://doi.org/10.18517/ijaseit.8.4.1528

Haryati, S., Rahmatullah, \& Putri, R.W. (2018).Torrefaction of Durian peel and bagasse for biobriquette as an alternative solid fuel. IOP Conf. Ser.: Mater. Sci. Eng. ,334 012008. https://doi.org/10.1088/1757-899X/334/1/012008

Haykiri-Acma, H., \& Yaman, S. (2010). Production of smokeless bio-briquettes from hazelnutshell. In Proceedings of the World Congress on Engineering and Computer Science, 2. WCECS, San Francisco, USA, 1-3.

Hu, Q., Shao,J., Yang, H., Yao, D., Wang, X., \& Chen, H. (2015). Effects of binders on the properties of bio-char pellets. Appl. Energy, 157, 508-516.

Idris, R., Yuliansyah,A.T., \& Purwono, S. (2018). Development of Biobriquette from Nutmeg Seed Shells. E3S Web of Conferences, 42 (01016). https://doi.org/10.1051/e3sconf/20184201016

Ifa, L., Yani, S., Nurjannah, N., Darnengsih, D., Rusnaenah, A., Mel, M., Mahfud, M., \& Kusuma, H.S. (2020). Techno-economic analysis of bio-briquette from cashew nutshell waste. Heliyon 6 , $1-9$. https://doi.org/10.1016/j.heliyon.2020.e05009

Ifa, L., Yani, S., Nurjannah, N., Sabara, Z., Yuliana, Y., Kusuma, H.S., Mahfud, M. (2019). Production of bio-briquette from biochar derived from pyrolysis of cashew nut waste. Ecol. Environ. Conserv., 25 (Suppl. Issue), S125-S131.

Irhamni , Saudah , Diana, Ernilasari , \& Suzanni, M. A. (2019).Utilization of Durian Shell Waste With Janeng Pati as a Raw Material of Briquette for Renewable Energy. IOP Conference Series Material Science Engineering. 536 (1), 012078. $899 X / 536 / 1 / 012078$

Kaliyan, N., \& Morey, R.V. (2009). Factors affecting strength and durability of densified biomass products. Biomass and 
Bioenergy,

33

337-359.

https://doi.org/10.1016/j.biombioe.2008.08.005

Kaur, A., Roy, M., \& Kundu, K. (2017). Densification of Biomass by Briquetting: A review. International Journal of Recent Scientific Research, 8 (10), 20561-20568. http://dx.doi.org/10.24327/ijrsr.2017.0810.0916

Kpalo, S.Y. \& Zainuddin, M.F. (2020). Briquette from Agricultural Residues; An Alternative Clean and Sustainable Fuel for Domestic Cooking in Nasarawa State, Nigeria. Scientific $\begin{array}{llll}\text { and } \quad \text { Academic, } & 10 & \text { (2), } & \text { 40-47. }\end{array}$ https://doi.org/10.5923/j.ep.20201002.03

Kpalo, S.Y., Zainuddin, M.F., Manaf, L.A., \& Roslan, A.M. (2020). A Review of Technical and Economic Aspects of Biomass Briquetting. https://doi.org/10.3390/su12114609

Lonia, B. (2005). Studies in techno economic aspects of power generation from agriwaste in India (Doctoral dissertation). http://hdl.handle.net/10603/222725

Lubwama, M.,Yiga, V.A. \& Lubwama, H.N. (2020), Effects and interactions of the agricultural waste residues and binder type on physical properties and calorific values of carbonized briquettes. Biomass Conversion and Biorefinery. $\quad$ https://doi.org/10.1007/s13399-02001001-8

Lubwama,M. , \& Yiga, V.A. (2018). Characteristics of briquettes developed from rice and coffee husks for domestic cooking applications in Uganda. Renewable Energy, 118, 43-55. https://doi.org/10.1016/j.renene.2017.11.003

Madhava,M., Prasad, B.V.S., Koushik,Y., Babu, K.R., \& Srihari, R. (2012). Performance evaluation of a hand operated compression type briquetting machine. J. Agric. Eng., 49 (2), 46-49.

Maia, B.G.D.O., Souza, O., Marangoni, C., Hotza, D., Oliveira, A.P.N.D., \& Sellin, N. (2014). Production and characterization of fuel briquettes from banana leaves waste. Chem. Eng. Transact., 37, 439-444. https://doi.org/10.3303/CET1437074

Maitah, M., Prochazka, P., Pachmann, A., Sredl, K., \& Rezbova, H. (2016). Economics of Palm Oil Empty Fruit Bunches BioBriquettes in Indonesia. International Journal of Energy Economics and Policy, 6(1).

Maninder, Kathuria, R.S., \& Grover, S. (2012). Using Agricultural Residues as a Biomass Briquetting: An Alternative Source of Energy. IOSR Journal of Electrical and Electronics Engineering, 1(5), 11-15.

Mari, R. (2014). Torrefied and carbonized wood, fuel properties and turn of exothermic reaction [Master's Thesis]. Helsingin yliopisto. http://urn.fi./URN:NBN:fihulib201507212300

Mieldažys, R., Jotautienè, E., Pocius, A., \& Jasinskas,A. (2016). Analysis of organic agricultural waste usage for fertilizer production. Agronomy Research,14 (1), 143$149 . \quad$ https://agronomy.emu.ee/wpcontent/uploads/2016/05/Vol14-_nr1_Mieldazys.pdf

Mitan, M.M., \& Muhammad, F.R.S. (2019). Temperature Effect on Densification of Banana Peels Briquette. Materials Today: Proceedings 19, Part 4,1403-1407. https://doi.org/10.1016/j.matpr.2019.11.159

Moki, E.C., Rapheal, I. A., Gusau, H. L., Abimbola, A. I., \& Harrison, O. (2018). Effect of Binder on Physicochemical Properties of Fuel Briquettes Produced from Watermelon Peels. AASCIT Journal of Energy, 5(2),23-27.

Mukhtar, H., Feroze, N., Munir, M.S., Javed, F., \& Kazmi, M. (2020). Torrefaction process optimization of agriwaste for energy densification, Energy Sources, Part A: Recovery, Utilization, and Environmental Effects.Energy Sources, Part A: Recovery, Utilization, and Environmental Effects, 42(20),

2526-2544. https://doi.org/10.1080/15567036.2019.1609626
Ngusale, G.K., Luo, Y., \& Kiplagat, J.K. (2014). Briquette making in Kenya: Nairobi and peri-urban areas. Renew. Sust.

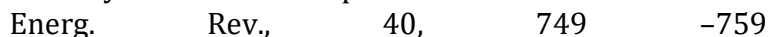
https://doi.org/10.1016/j.rser.2014.07.206

Nurhayati, A.Y., Hariadi, Y.C., \& Hasanah, W. (2016). Endeavoring to Food Sustainability by Promoting Corn Cob and Rice Husk Briquetting to Fuel Energy for Small Scale Industries and Household Communities. Agriculture and Agricultural Science Procedia, 9, 386 - 395. https://doi.org/ 10.1016/j.aaspro.2016.02.154

Nuriana,W, Anisa,N., \& Martana (2014). Synthesis Preliminary Studies Durian Peel Bio-Briquettes as an Alternative Fuels. Energy Procedia, 47, 295 - 302. http://dx.doi.org/10.1016/j.egypro.2014.01.228

Obeng, G.Y., Amoah, D.Y., Opoku, R., Sekyere, C.K., Adjei,E.A., \& Mensah, E. (2020). Coconut wastes as Bioresource for sustainable energy: quantifying wastes, calorific values and emissions in Ghana. Energies, 13 (9), 2178. https://doi.org/10.3390/en13092178

Obi, F.O., Ugwuishiwu, B.O., \& Nwakaire, J.N. (2016). Agricultural waste concept, generation utilization and management. Nigerian Journal of Technology, 35(4), 957-964. https://dx.doi.org/10.4314/njt.v35i4.34

Okot, D.K. (2019). Briquetting and Torrefaction of Agricultural Residues for Energy Production (Doctoral dissertation). http://theses.ncl.ac.uk/jspui/handle/10443/4716

Oladeji, J. T. (2015).Theoretical Aspects of Biomass Briquetting: A Review Study. Journal of Energy Technologies and Policy, 5(3),72-81.

Onchieku, J.M., Chikamai, B.N., \& Rao, M.S. (2012). Optimum parameters for the formulation of charcoal briquettes using bagasse and clay as binder. Eur. J. Sust. Dev., 1(3), 477-492. https://doi.org/10.14207/ejsd.2012.v1n3p477

Onuegbu, T.U., Ogbu, I.M., Ilochi, N.O., Ekpunobi, U.E., \& Ogbuagu, A.S. (2010). Enhancing the properties of coal briquette using spear grass (Imperata Cylindrica). Leonardo Journal of Sciences, 9(17), 47-58.

Pallavi, H.V., Srikantaswamy, S., Kiran, B.M., Vyshnavi, D.R., \& Ashwin, C.A. (2013). Briquetting agricultural waste as an energy source. J. Environ. Sci. Comput. Sci. Eng.Technol., 2 (1), 160-172.

Pestaño, L.D.B., \& Jose, W.I. (2016). Production of Solid Fuel by Torrefaction Using Coconut Leaves as Renewable Biomass. Int.Journal of Renewable Energy Development, 5 (3), 187-197.http://dx.doi.org/10.14710/ijred.5.3187197

Quartey, E.T. (2011). Briquetting agricultural waste as an energy source in Ghana. ResearchGate, 200-204.

Rahaman, S.A., \& Salam, A.P. (2017). Characterization of cold densified rice straw briquettes and the potential use of sawdust as binder. Fuel Processing Technology, 158, 9-19. http://dx.doi.org/10.1016/j.fuproc.2016.12.008

Rezvani, Z., Chengini, G.R., Arabhosseini, A., \& Klanmehr, M.H. (2013). Environmental control with recycling of rice straw briquettes. J. Automot. Appl. Mech., 1(1).

Rijal, K., \& Sapkota, R.P. (2017). Bio-Briquette: rural energy option for mitigating climate change. In A. Prasad, S.S. Katewa \& S. Daunde (Eds.), The International Conference entitled "Eco Friendly and Socially Responsive Economy and Equity: Issues and Challenges of 21st Century for Emergent Sustainable Development Amongst SAARC Countries (314-323).

Román-Figueroa, C., Montenegro N, \& Paneque M. (2017). Bioenergy potential from crop residue biomass in Araucanía region of Chile. Renewable Energy. 102:170177. 
Saikia, M., \& Baruah, D. (2013). Analysis of physical properties of biomass briquettes prepared by wet briquetting method. Int. J. Eng. Res. Dev., 6 (5), 12-14.

Saptoadi, H. (2008). The Best Biobriquette Dimension and its Particle Size. Asian J. Energy Environ., 9(3,4),161-175.

Saputro, E.A., Billah, M., Laksminingsih, A., Mardiansyah, Y. E., Yogaswara, R. R., \& Erliyanti, N. K. (2020). Utilizing organic waste (sugarcane bagasse and sugarcane leaves) as bio briquettes through pyrolysis process. 1st International Conference Eco-Innovation in Science, Engineering, and Technology. NST Proceedings, 216-220. https://doi.org/10.11594/nstp.2020.0534

Sari, E., Pasymi, Khatab, U., Desmiarti, R., Ariansyah, R., Hariadi, \& Sutra (2018). Studies of carbonization process on the production of durian peel biobriquettes with mixed biomass coconut and palm shells. IOP Conf. Ser.:Mater. Sci. Eng., 316 012021. https://doi.org/10.1088/1757899X/316/1/012021

Scarlat, N., Dallemand, J. F., Monforti-Ferrario, F., \& Nita, V. (2015). The role of biomass and bioenergy in a future bioeconomy: policies and facts. Environ. Dev.,15,3 - 34. https://doi.org/10.1016/j.envdev.2015.03.006.

Sharma, M. K., Priyank, G., \& Nikita, S. (2015). Biomass briquette Production: a propagation of non-convention technology and future of pollution free thermal energy sources. Am. J. Eng.Res., 4 (2), 44-50.

Shuma, R., \& Madyira, D. M. (2017). Production of loose biomass briquettes from agricultural and forestry residues. Procedia Manufacturing, 7,98-105. https://doi.org/10.1016/j.promfg.2016.12.026

Sirajudin, N., Jusoff, K., Yani, S., Ifa, L., \& Roesyadi, A. (2013). Biofuel production from catalytic cracking of palm oil. World Appl. Sci. J., 26, 67-71. https://10.5829/idosi.wasj.2013.26.nrrdsi.26012

Sivakumar, K., \& Mohan, N.K. (2010). Performance analysis of downdraft gasifier for agriwaste biomass materials. Indian J. Sci. Technol., 3, 58-60.

Solano, D., Vinyes, P., \& Arranz, P. (2016). Biomass briquetting process (A guideline report). A UNDP / CEDRO.

Stolarski, M.J., Szczukowski, S., Tworkowski, J., Krzyzaniak, M., Gulczynski, P., \& Mileczek, M. (2013). Comparison of quality and production cost of briquettes made from agricultural and forest origin biomass. Renew. Energy, 57, 20-26.

Suryaningsih, S., Nurhilal, O., Yuliah, Y., \& Mulyana, C. (2017). Combustion quality analysis of briquettes from variety of agricultural waste as source of alternative fuels. IOP Conf. Series: Earth and Environmental Science,65, 012012. https://doi.org/10.1088/1755-1315/65/1/012012

Suryaningsih, S., Nurhilal, O., Yuliah, Y., \& Salsabila, E. (2018). Fabrication and Characterization of Rice Husk Charcoal Bio Briquettes. AIP Conference Proceedings, 1927, 030044. https://doi.org/10.1063/1.5021237

Suvunnapob, S., Ayudhya, B.I.N., \& Kusuktham, B. (2015). A study of cotton dust mixed with wood dust for biobriquette fuel. Eng.J., 19 (4), 57-70.

Talukdar, A., Das, D., \& Saikia, M. (2014). Study of Combustion Characteristics of Fuel Briquettes. International Journal of Computational Engineering Research Issn., 4 (3), 2250 3005.

Tan, X., Liu, S., Liu,Y., Gu,Y., Zeng, G.,Hu, X., Wang,X., Liu,S., \& Jiang, L.H. (2017). Biochar a potential sustainable precursor for activated carbon production: multiple applications in environmental protection and energy storage. Bioresource. Technol., 227, 359-372.

Tiwari, Chesta, \& Beck, S. (2011). Producing fuel briquettes from sugarcane waste. EWB-UK National Research \& Education Journal, 220-550.

Ugwu, K., \& Agbo, K. (2013). Evaluation of binders in the production of briquettes from empty fruit bunches of Elais Guinensis. Int. J. Renew. Sust. Energy., 2 (4) ,176179.

Ujjinappa, S., \& Sreepathi, L.K. (2018). Evaluation of physicomechanical-combustion characteristics of fuel briquettes made from blends of areca nut husk, simarouba seed shell and black liquor. Int. J. Renew. Energy Dev., 7 (2), 131137.

Uyan, M. (2013). GIS-based solar farms site selection using analytic hierarchy process (AHP) in Karapinar region, Konya/Turkey. Renewable and Sustainable Reviews, 28: 11-17.

Uzun, B.B., \& Kanmaz, G. (2013). Effect of operating paramters on bio-fuel production from waste furniture sawdust. Waste Management. Res., 31, 361-367.

Villegas, I. B., Gutiérrez, M. S., Rodríguez, F. P., Espinosa, E., \& Rodríguez, A. (2021). Lignocellulose Nanofifibre Obtained from Agricultural Wastes of Tomato, Pepper and Eggplants Improves the Performance of Films of Polyvinyl Alcohol (PVA) for Food Packaging. Foods, 10, 3043. https://doi.org/10.3390/foods10123043

Wakchaure,G.C., \& Mani, I. (2009). Effect of Binders and Pressures on Physical Quality of Some Biomass Briquettes. Journal of Agricultural Engineering, 46(4), 2430.

Wakchaure,G.C., \& Mani,I. (2011). Thermal and Storage Characteristics of Biomass Briquettes with Organic Binders. Journal of Agricultural Engineering, 48(4), 43-53.

Wang, Z., Lei, T., Yang, M., Li, Z., Qi, T., Xin X., He, X., Ajayebi, A., \& Yan, X. (2017). Life cycle environmental impacts of cornstalk briquette fuel in China. Applied Energy, 192, 83-94. http://dx.doi.org/10.1016/j.apenergy.2017.01.071

World Bioenergy Association (2019). Global Bioenergy Statistics 2019.

Wu, S., Zhang, S., Wang, C., Mu, C., \& Huang, X. (2018). Highstrength charcoal briquette preparation from hydrothermal pretreated biomass wastes. Fuel Processing Technology, 171,293-300. https://doi.org/10.1016/j.fuproc.2017.11.025

Yank, A., Ngadi, M., \& Kok, R. (2016). Physical properties of rice husk and bran briquettes under low pressure densification for rural applications. Biomass and Bioenergy, $\quad$ 84,22-30. http://dx.doi.org/10.1016/j.biombioe.2015.09.015

Zanella, K., Gonçalves, J.L., \& Taranto, O.P. (2016). Charcoal briquette production using orange bagasse and corn starch. Chem. Eng. Transact., 49, 313-318.

Zhang, G., Sun, Y., \& Xu, Y. (2018). Review of briquette binders and briquetting mechanism. Renewable and Sustainable Energy Reviews, 82,477-487. http://dx.doi.org/10.1016/j.rser.2017.09.072

Zhang, Y.,Cui, Y., Chen, P., Liu, S., Zhou, N., Ding, K., Fan, L., Peng, P., Min, M., Cheng, Y.,Wang, Y., Wan Y., Liu Y., Li, B., \& Ruan, R. (2019). Chapter-4 Gasification Technologies and Their Energy Potentials. Sustainable Resource Recovery and Zero Waste Approaches, 193-206. https://doi.org/10.1016/b978-0-444-64200-4.00014-1 